\title{
Haze, Hunger, Hesitation: Disaster Aid after the 1783 Lakagígar Eruption
}

\author{
Claudia E. Wieners (Institute of Economics, Scuola Superiore Sant'Anna, Pisa, Italy*
}

\begin{abstract}
The 1783-1784 Lakagígar eruption was probably the most severe natural catastrophe to occur in Iceland. While contemporary records suggest that no or few human lives were lost directly due to the eruption, vegetation damage by acid rain and fluorine poisoning caused a massive decimation of livestock, which led to a famine lasting 1.5 years. Contagious diseases also took many lives, but may be an indirect result of hunger. 18th Century Iceland was a Danish dependency and a subsistence farming community highly vulnerable to famine. Development of the fisheries could have improved the situation, but this did not occur. Instead, Iceland remained trapped in a vicious circle of conservatism, poverty, and lack of technological means (seaworthy fishing boats) sustained by artificially low fish prices decreed by the Danish king. During the famine, the Danish government was in principle willing to provide relief. However, local authorities in Iceland were slow to ask for help, and did not dare to exploit the means at their disposal (e.g. the right to ban the export of Icelandic foodstuff) without consent from Copenhagen. The Danish officials in turn were unwilling to act decisively upon incomplete information. These two factors prevented timely measures. While $4.4 \times 10^{5} \mathrm{~kg}$ of grain were provided for famine relief in summer 1784 , the merchants exported $1.2 \times 10^{6} \mathrm{~kg}$ of fish, which greatly aggravated the hunger in the second winter. The effects of this 'natural' catastrophe could therefore have been significantly reduced by efficient government.
\end{abstract}

Keywords: Iceland; volcanic eruption; famine; disaster aid

\section{Introduction}

The 1783 Lakagígar eruption was, in terms of lava output, the second largest eruption in Iceland since the country was inhabited around AD870. Lasting from June 8th, 1783 to February 1784, it produced about $15 \mathrm{~km}^{3}$ of lava, covering an area of around $600 \mathrm{~km}^{2}$, spread fine poisonous ash over most of the island, and produced a persistent sulphurous haze which was observed over large parts of the Northern hemisphere[Thordarson and Self, 1993, Thordarson and Self, 2003]. The so-called Haze Hardships (Móðuharðindin) caused by the eruption were probably the worst natural catastrophe which befell Iceland, and may have killed 1/6 of the human population. However, few, if any, of the deaths were caused directly by the eruption, i.e. by lava streams, tephra fall or gas poisoning. Written accounts (e.g. [Steingrímsson, 1788, Guðjónsson, 2010]) agree that the main causes were starvation - brought about by a massive loss of livestock - and non-specified contagious diseases [Hálfdanarson, 1894]. These human deaths are often presented as an inevitable consequence of the eruption: Acid rain and poisonous ash killed the sheep and cows, thus (obviously) people starved.

Much less attention, at least in the English literature, is devoted to the question why the Icelandic population was so vulnerable to the impacts of the eruption, and whether or how the human suffering could have been mitigated. As can be seen in fig. 1, mortality did not surge immediately after the onset of the eruption. For example, Reverend Jón Steingrímsson, who served in the parish Kirkjubæjarklaustur close to the eruption, observed that "until the beginning of the year 1784 the number of deaths [...] was not great. But [...] as the winter passed, the number grew and grew." [Steingrímsson, 1788, p.78]. A similar picture arises for the rest of Iceland. Thus there was a time window of about half a year in which mitigation measures could have been taken, and even 1.5 years to prevent the second peak of starvation in the winter of $1784 / 85$ (see fig. 1). Perhaps remarkably for those times, the government of Denmark - of which Iceland was a dependency - was in principle willing to provide significant famine relief, but on the whole the operation failed, owing to a combination of inflexible government structures, slow communication, hesitation to act upon incomplete information, conflicting interests of involved parties and sheer bad luck.

*c.wieners@santannapisa.it 


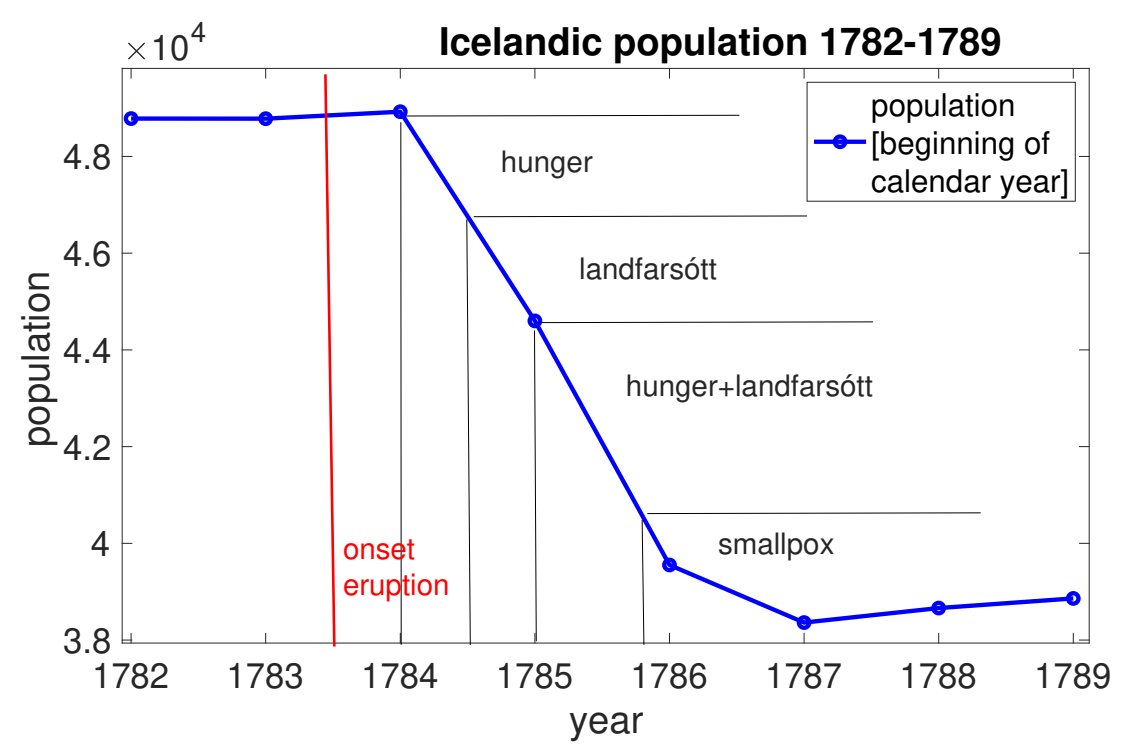

Figure 1: Population of Iceland, 1782-1789, and main causes of death ('landfarsótt' being non-specified contagious diseases). Based on data from [Hálfdanarson, 1894].

This article reviews the (partly Icelandic and Danish) literature on the economic and societal impacts of the Lakagígar eruption, to provide an overview of 1) the hazards emerging from the eruption, both in Iceland and beyond, 2) the historical circumstances causing the high vulnerability of the Icelandic society, and 3) the attempts by the Danish government to provide famine aid. The article may therefore provide both a useful reference for scholars investigating the Lakagígar eruption, and an interesting case study of the complexity of "natural" disasters and disaster relief.

It is textbook wisdom in disaster risk reduction that risk is determined by hazard exposure, vulnerability, and coping capability. The next three sections are structured along this line of thought. Section 2 (exposure) briefly discusses the geophysical hazards and their direct and indirect effects on human health and mortality. Section 3 (vulnerability) outlines the socio-economic situation that made Iceland so prone to famine. Section 4 (capability) describes how Icelandic and Danish authorities tried to cope with the disaster. Next, section 5 summarises possible long-term effects of the eruption, while section 6 discusses in more general terms the reasons for the meagre effects of relief actions, and - in the vein of [Keating et al., 2016] - possible lessons to be drawn.

\section{Hazard exposure: Fire, Fog and Frost}

There already exists an extensive literature on physical aspects of the eruption, see e.g. [Thordarson and Self, 1993, Thordarson et al., 2003, Thordarson and Self, 2003] on geological, [Thordarson and Self, 2003, Schmidt et al., 2011] on environmental, and [Lanciki et al., 2012, Schmidt et al., 2012, Zambri et al., 2019a, Zambri et al., 2019b] on climatological effects. Here, only a brief summary will be given. A little more will be said about the consequences on the human population, in particular various factors contributing to the high mortality rates, in the light of contemporary records.

\subsection{Effects in Iceland}

\subsubsection{Local effects: Lava and tephra fall}

The eruption took place along a volcanic fissure of about $25 \mathrm{~km}$ length which is known as Lakagígar (craters of Laki) and is part of the Grímsvötn volcanic system [Thordarson and Self, 1993]. The flood basalt eruption started on June 8th, 1783, and consisted of 10 episodes beginning with explosive activity (due to lava degassing and violent interaction with ground water) followed by more effusive lava flow. The total lava output was estimated to be $15 \mathrm{~km}^{3}$, covering an area of ca. $600 \mathrm{~km}^{2}$. Although the fissure itself is situated in the uninhabited highlands, lava followed two river valleys into inhabited areas [Steingrímsson, 1788, Thordarson et al., 2003]. The first episodes, until about July 20th, occurred on the western part of the fissure and their lava flowed into the Skaftá river, evaporating the 

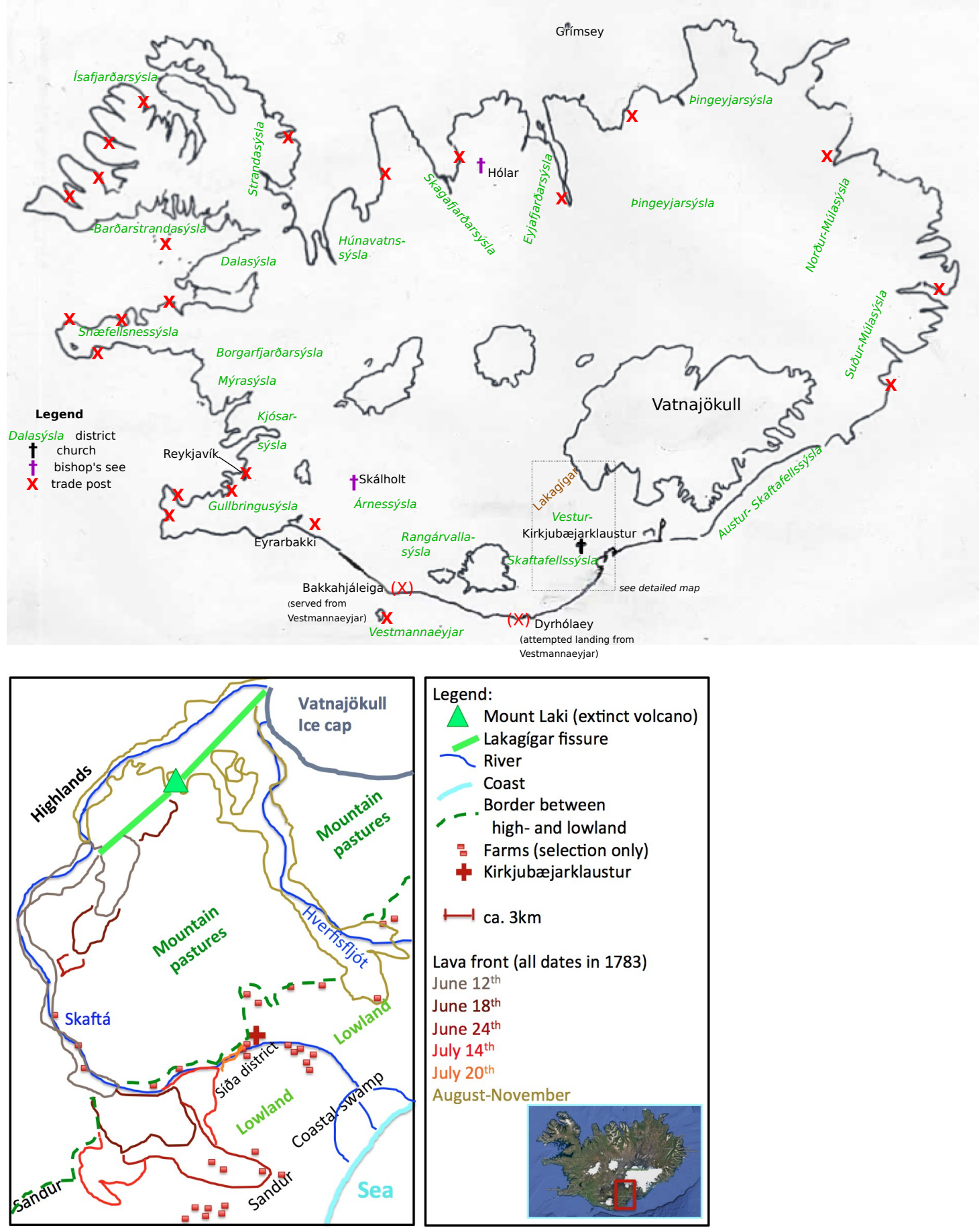

Figure 2: Top: Overview map of Iceland, with districts and trade posts in 1783 (the latter taken from [Gunnarsson, 1983]). Bottom: Detailed map of the surroundings of the Lakagígar (based on [Guðbergsson and Theodórsson, 1984] and [Thordarson and Höskuldsson, 2014, chap. 6.3]). 


\begin{tabular}{|c||c|c|c|}
\hline & 1703 & $1785(\%$ of 1703$)$ & 1795 \\
\hline \hline Cattle & 35860 & $16592(46 \%)$ & 22488 \\
\hline Horses & 26909 & $12786(48 \%)$ & 22599 \\
\hline Sheep & 278994 & $64459(23 \%)$ & 241171 \\
\hline
\end{tabular}

Table 1: Number of farming animals in Iceland before, 2 years after, and 12 years after the Lakagígar eruption. Based on data from [Rafnsson, 1984a].

river water and following its bed to the lowlands, where it spread over the pastures and destroyed several farms. Other farmsteads were destroyed by inundation (after tributaries of the Skaftá became blocked by lava), by tephra fall and by sand storms (partly sand from the exposed beds of the dried-up Skaftá river). From August onward, the eruption shifted to the eastern half of the fissure, and the lava followed the Hverfisfljót river, again destroying several farms. The eruption ceased in February 1784.

In total, 42 farmsteads $(\approx 0.8 \%$ of all Icelandic farms) were given up either temporally or permanently directly because of these physical effects of the eruption [Guðbergsson and Theodórsson, 1984]. No human lives were taken by the eruption itself, but several hundred persons had to leave their homes. Some of them stayed in the neighbourhood, e.g on farms given up by their neighbours, while about 500 out of 1964 people from Vestur-Skaftafellsýsla left the district, mostly moving west, either to other farms or to the fishing districts (e.g. Vestmannaeyjar, Gullbringusýsla) [Gunnlaugsson, 1984a]. In the two communes closest to the volcano, Leiðvallarhreppur and Kleifahreppur, the number of inhabitants fell from about 1300 in 1783 to 525 in 1784 [Guðbergsson and Theodórsson, 1984], partly due to migration, partly due to death.

\subsubsection{Distal effects: Fine ash and volcanic haze}

While the lava was clearly a local hazard, volcanic haze and ash fall affected almost all of Iceland. Fine ash produced by lava fragmentation during explosive episodes - spread over most of the country. Although the tephra layer in most regions was not thick enough to physically damage vegetation, the fine ash carried highly toxic fluorine. Fluorine can be adsorbed on fine ash particles but is subsequently washed into the ground by rainfall. Measurements of gas vesicles in the Lakagígar lava combined with observations from later eruptions suggest that the fluorine content of (dried) gras was well above lethal dose for grazing animals [Thordarson and Self, 2003].

The Lakagígar magma was rich in gas. It was estimated that roughly $120 \mathrm{Mt}$ of SO2 were emitted, of which about $80 \%$ were carried by eruption plumes into the high troposphere and/or low stratosphere, while about $20 \%$ slowly degassed from the lava streams [Thordarson and Self, 2003]. SO2 reacts with water to form droplets of sulphuric acid (H2SO4), which led to the formation of a thick, "dry", acidic haze and acid rain. The latter caused serious damage to vegetation, with grass and wild plants "withering to the roots" [Steingrímsson, 1788, Guðjónsson, 2010]. Since the eruption was strongest during the summer months, the hey harvest was severely affected. The harvest failure together with the fluorine poisoning [Pétursson et al., 1984] caused massive reduction of the livestock (see table 1). Wild animals (birds, fresh water fish) and plants (lyme grass, berries, Icelandic moss), which served as secondary food suppliers, were also much diminished due to the eruption [Steingrímsson, 1788, Pétursson et al., 1984]. Salt water fisheries, on the other hand, were hardly affected, except for local and temporary navigation difficulties due to the dense fog.

It has occasionally been suggested that pollution from the Lakagígar eruption may have significantly contributed to mortality crises inside and outside Iceland. For example, it was proposed [Schmidt et al., 2011] that "Icelandic records clearly suggest that air pollution contributed directly to increased mortality rates, with northern regions repeatedly exposed to a low-level sulphuric acid haze suffering much higher death rates than other regions". However, a closer look at contemporary Icelandic records does not support this notion. It is true that the acid haze caused some health problems. For example, Reverend Jón Steingrímsson, whose parish was closest to the volcano, mentions respiratory disorders such as difficult breathing, especially with persons suffering from pre-existing chest diseases, and irritated throats, skin and eyes [Steingrímsson, 1788, p. 41]. Extant contemporary letters by officials from the north hardly mention health issues in summer-autumn 1783. One letter from Svarfaðardalshreppur in Eyjafjarðarsýsla [Sigurðsson and Bergsson, 1783] briefly mentions "disgusting stench and ill odour, such that men with [pre-existing] breast diseases temporarily stayed in bed". This hardly supports the notion of a major health crisis due to pollution. Neither does the mortality data referred to by [Schmidt et al., 2011] (see fig. 3), if timing is considered. It is known that during smog situations, mortality follows pollution at time lags of at most some days. For instance, during the Great London Smog of 1952, each peak in haze density was immediately followed by an increase in mortality, although mortality remained elevated for some weeks after the haze was gone 
[Bell and Davis, 2001]. However, in Iceland in 1783, mortality was below average in 11 out of 16 deaneries. In the Skaftafellssýslur, the deanery closest to the Lakagígar, 1783 mortality was only $5 \%$ above the average over 1778-1782. The highest values, $50 \%$ and $14 \%$ above the average, in Pingeyjarsýsla and the Múlasýslur, respectively, may well have been related to the meagre hay harvest 1782 and harsh winter weather 1782-83 in Northeast Iceland: The annal Höskuldsstaðaannáll records "Great hardships in Pingeyjarsýsla due to lack of grass", [Guðjónsson, 2010]. The reason for the higher death rates in the north in 1784-1785 can be explained by the region's particularly high vulnerability to famine (see sect. 3.2).

There is also no clear evidence for fluorine poisoning in humans. Some symptoms in contemporary records [Steingrímsson, 1788, p. 77-78] and [Stephensen, 1785, p. $128 \mathrm{ff}]$ resemble to some extent the symptoms found in fluorine-affected animals (e.g. loss of hair, swellings) and might thus hint at human fluorine poisoning, but can also be explained by scurvy [Roholm, 1937, Ch. XXVIII.1]. Other classical scurvy symptoms like swollen gums and loss of teeth were also observed in humans [Steingrímsson, 1788, p. 77-78] but are unrelated to fluorine poisoning [Pétursson et al., 1984]. To make matters more complicated, it has been suggested that scurvy and fluorine poisoning might interact, e.g. fluorine might affect the utilisation of vitamin C [Roholm, 1937, Ch. XXVII.5] whereas vitamin C helps to reduce the effects of fluorine [Gupta et al., 1996]. To summarise, we can not exclude that volcanic pollution killed some individuals in Iceland, but on the whole, contemporary sources do not support the notion of direct effects of pollution being a major driver of human mortality during the Haze Hardships 1783-85.

\subsubsection{Hunger and Contagious Diseases}

Contemporary records all agree that the decimation of livestock and wildlife, brought about by the eruption and subsequent bad weather, gave rise to a wide-spread famine, with people starting to die in December 1783 . The famine lasted till summer 1785. As mentioned in the introduction, the Icelandic population declined from about 48925 at the end of 1783 to about 38360 by the end of 1786 , and it has often been stated that the Lakagígar eruption killed $22 \%$ of the Icelanders. However, not all of these deaths can be clearly attributed to starvation (and hence, indirectly, to the eruption). Around 1500 deaths were caused by a smallpox epidemic 1785-1787, which raged when the famine had abated and may well have been unrelated to the eruption, as smallpox epidemics were common at the time (a far more virulent smallpox epidemic had killed about $1 / 4$ of the Icelandic population in 1707-09). In addition, parish records also name illnesses ('landfarsótt') as an important cause of death [Hálfdanarson, 1894] during the years 1784-85. In those parishes where detailed records are available (covering about $1 / 12$ of the total population), more people are listed as having died from landfarsótt (233 persons) than from hunger (174 persons), while a great number of persons (562) died from other or unspecified reasons.

The word landfarsótt literally means 'land-travelling disease' and seems to have been used rather undiscriminatively for many endemic, contagious diseases, but not distinct epidemics like smallpox [Hálfdanarson, 1894]. The smallpox epidemic of 1785-1787 very likely only arrived in August 1785 with a Danish ship, while landfarsótt raged mostly in autumn 1784 and spring 1785. The connection between landfarsótt and hunger is subtle. [Hálfdanarson, 1894] showed that landfarsótt was probably not merely deficiency diseases connected to malnutrition (such as scurvy), because landfarsótt and hunger showed different timings (hunger deaths being more abundant during spring 1784 and spring 1785, i.e. when food reserves were lowest after winter). In addition, landfarsótt attacked all social strata, whereas hunger especially affected the poorest (vagabonds, paupers, farmhands); and landfarsótt especially killed the very young and the elderly, while hunger deaths were more evenly distributed over all age groups. Finally, landfarsótt was mainly prevalent in the west of Iceland, where few hunger death were recorded, while only few landfarsótt cases occurred in the famine-ridden north.

On the other hand, it is known that during famines seemingly unrelated (endemic) diseases also surge, due to impaired immune resistance or indirect factors, such migration and deteriorating sanitary conditions [Ó'Gráda, 2007]. Even in the west of Iceland, people suffered hunger. For example, the district overseer (sýslumaður) Jón Arnórsson of Snæfellssýsla, a district in western Iceland with good fishing grounds and some farms, wrote that the district (sýsla) had lost considerable amounts of livestock and 40 farms had been given up as farmers fled to the coast to save their life by fishing [Arnórsson, 1784]. The fishermen also suffered, because they could not exchange part of their catch for farming products (butter, wool) and had to live on fish alone. So even if few people in this area actually starved, malnutrition was present. A second factor was the fugitives from northern and southeastern Iceland who flocked to the fishing districts - "a few hundred poor people [...] of both sexes and all age groups, no small burden to this district [Snæfellssýsla]" [Arnórsson, 1784] - probably leading to cramped accommodation, which together with the generally poor and unhygienic housing [Magnússon, 2010, p 48ff] may have favoured the spreading of diseases. If landfarsótt was indeed an indirect result of the famine, then the death toll of the Lakagígar eruption in Iceland may have been around 8500 persons, or $1 / 6$ of the 1783 population. 

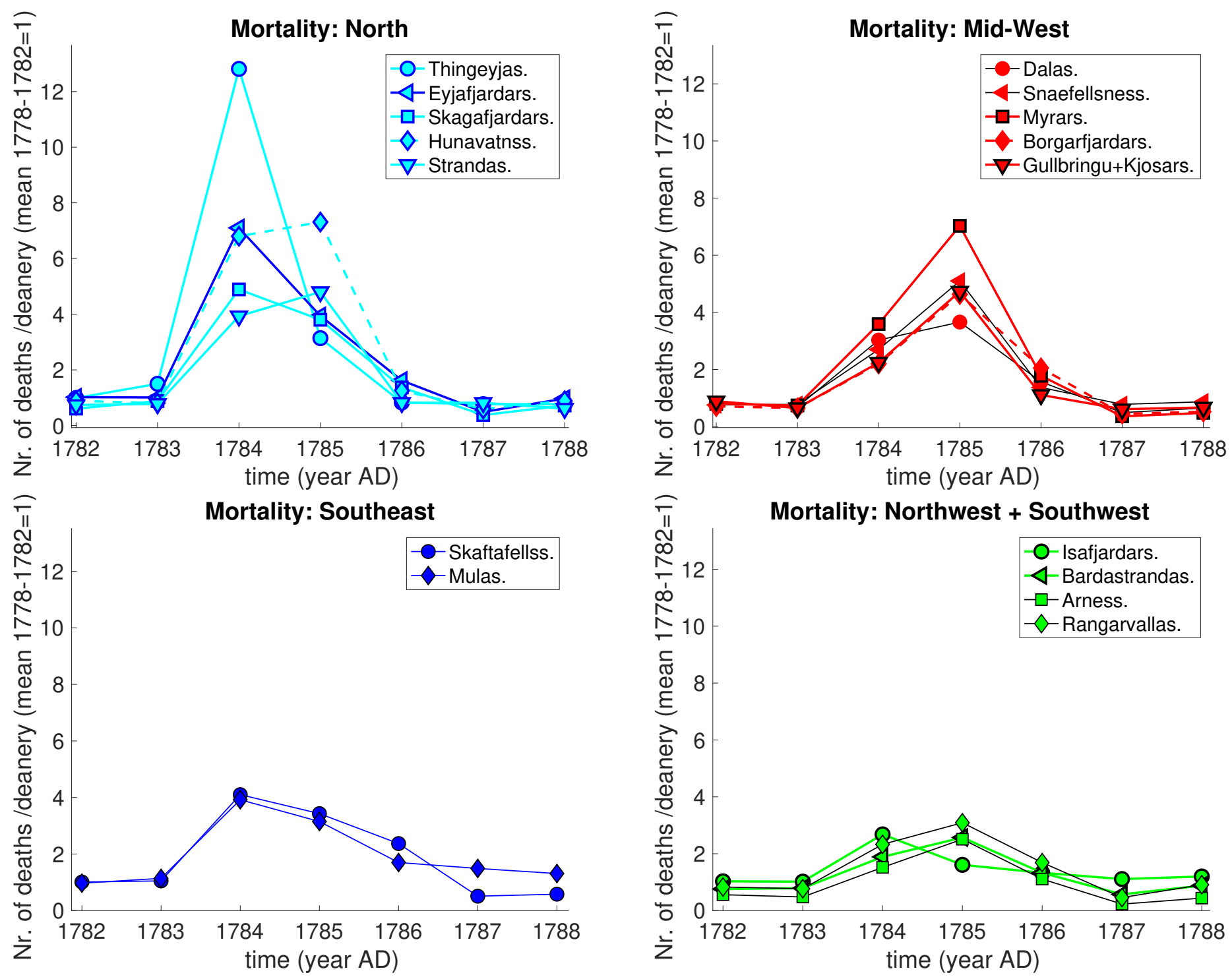

Figure 3: Number of deaths in Iceland, 1782-1788, per deanery, with the mean over 1778-1782 being normalised to 1. Over whole Iceland, the mean over those years was 30 deaths per 1000 inhabitants [Gunnarsson, 1983]. Deaneries were roughly equivalent to the districts shown in fig. 2, although sometimes two districts form one deanery (e.g. Vestur- and Austur-Skaftafellssýsla, Norður- and Suður-Múlasýsla). Plots based on data from [Hálfdanarson, 1894]. As pointed out in that study, the north of Iceland was particularly affected by hunger, and the mid-west by Landfarsótt. For the southeast, no data on death causes is present. The northwest and southwest were least affected by the eruption. 


\subsection{Effects beyond Iceland}

\subsubsection{Haze and air pollution outside Iceland}

The sulphuric haze was transported to western and mid Europe within a few days [Thordarson and Self, 2003]. While first only a relatively thin haze was observed, thick dry mist, blood-red sunsets and sulphur stench were found in July 1783. It gave rise to much panic and scientific speculation about its cause (fumes released during the severe earthquakes in Southern Italy of February 1783 being a frequently suspected source [Halldórsson, 2013, p. 45 $\mathrm{ff}]$ ), as the news about the Icelandic eruption only reached the outside world by the end of August. The sulphuric haze caused at least temporary damage to plant leaves [Halldórsson, 2013, p.79 ff], although no wide-spread harvest failures seem to have occurred [Halldórsson, 2013, p. 85 ff].

Parish records from England show increased mortality in August and September 1783, which has been linked to air pollution caused by the eruption [Grattan et al., 2003]. However, this interpretation raises some doubts. First, the western European mortality peak started several weeks after most of the haze there was already gone [Whitham and Oppenheimer, 2004], i.e. the time lag was considerable larger than during the Great London Smog. Second, as explained above, there was likely no surge in mortality in Iceland in the summer of 1783, although the concentration of pollutants should have been much higher there (unless maybe if the most dangerous pollutants were aerosol particles forming only slowly while the haze moved towards Europe). As an alternative hypothesis for the English mortality peak, [Whitham and Oppenheimer, 2004] suggested that a contagious disease might have been a cause, possibly triggered by an increase of disease-bearing insects due to the warm summer weather. No wide-spread loss of harvest was reported in those regions, let alone famine.

Note that even if the health effect of the Lakagígar eruption in Europe remains doubtful, it is still possible that a similar eruption in current times would have a severe impact, as suggested by [Schmidt et al., 2011]. Current background values of particulate matter are higher, making it more likely that a Lakagígar-style eruption would lead to crossing critical pollution thresholds.

\subsubsection{Impacts on the Climate}

The Lakagígar eruption was followed by large-scale weather anomalies, including a hot summer in central Europe in 1783, a cold winter in Europe and North America in 1783/84, northern hemispheric cooling for about 3 years [Thordarson and Self, 2003], and drought in the Nile catchment [Oman et al., 2006].

Explosive volcanic eruptions are known to influence the climate [Robock, 2000]. They inject large quantities of sulphur gas into the stratosphere, where it forms a sulphate aerosol veil that can last for several months because unlike tropospheric aerosol, it is not rained out quickly. The aerosol reflects part of the incoming solar radiation and hence cools the globe. In addition, it absorbs outgoing infrared radiation, thereby warming the stratosphere. If this warming is not spatially homogenous, horizontal temperature gradients are changed, which affects atmospheric circulation patterns. The Lakagígar eruption was predominantly effusive, and it is still discussed whether its sulphur output reached the stratosphere [Thordarson and Self, 2003, Lanciki et al., 2012, Schmidt et al., 2012].

An extensive model ensemble study suggests that the hot European summer was coincidence rather than caused by the eruption [Zambri et al., 2019b]. On the other hand, the study does find that the eruption may have contributed to the cold winter $1783 / 84$, both by direct cooling and by facilitating the negative NAO and the El Niño which have earlier been suggested as possible causes for the cold winter weather [d'Arrigo et al., 2011]. Precipitation reductions in the northern hemisphere tropics (including the Nile catchment) are also reproduced.

In Iceland, the winter 1783/84 was extremely cold, such that the animals had to be fed with the scarce hay, and the summer 1784 was cool and wet, inhibiting the new hay harvest [Guðjónsson, 2010]. Both may have aggravated the decimation of the animal stock.

\section{Vulnerability: The fish and sheep paradox}

Iceland in the 17th and 18th century was very vulnerable to famine, due to a combination of geographical, economic, and political factors. In addition, political and geographical factors greatly inhibited efficient disaster relief after the eruption.

\subsection{Absolutist government}

Iceland was a dependency of Denmark-Norway, and was ruled from Copenhagen. The administration was ordered in a very hierarchical fashion (see fig. 4), for Denmark-Norway was an absolutist monarchy. All power officially 
The administration of Iceland, around 1783

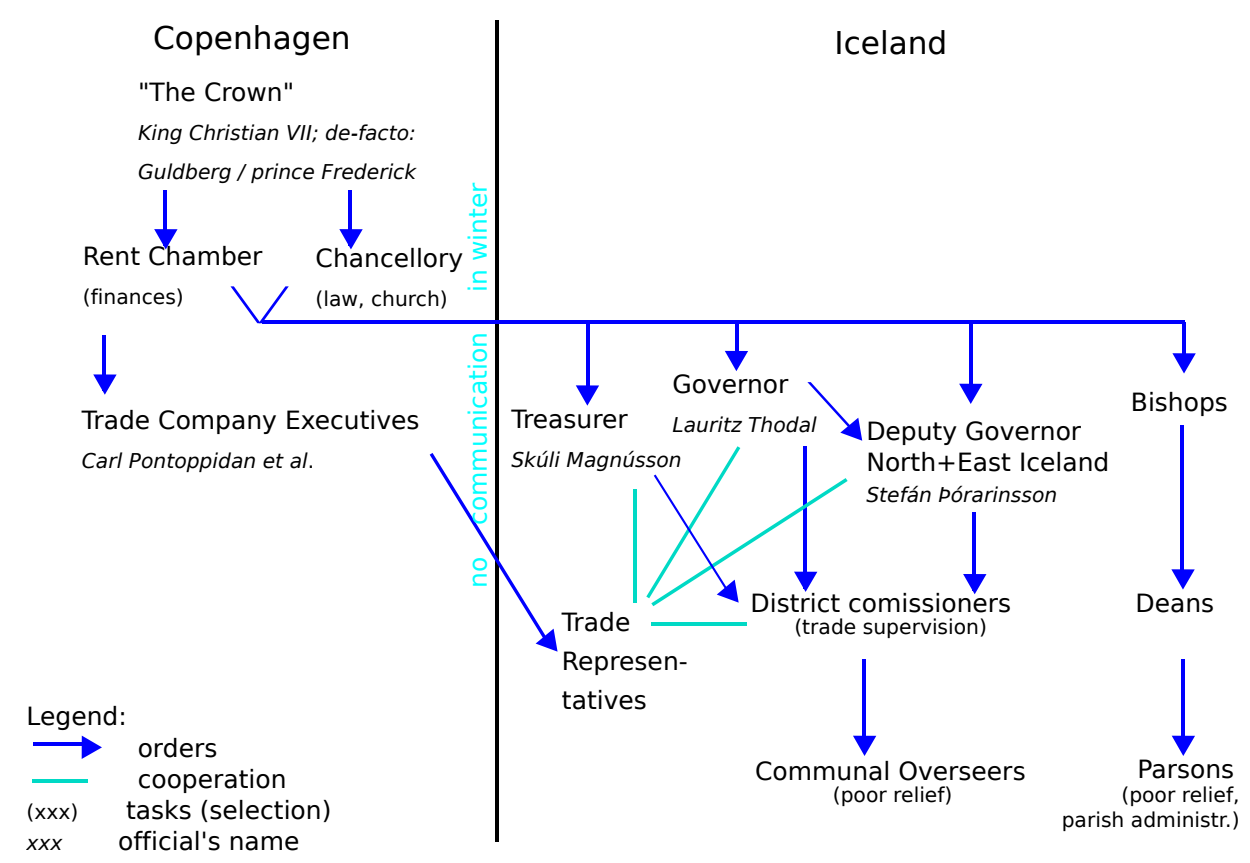

Figure 4: Structure of the administration of Iceland in the late 18th century. The names of the officials are for July 1783-April 1785.

lay with the King by God's grace, Christian VII. The king was, however, mentally ill and unable to reign, and de facto the power lay with those who attained control over the king. From 1772, this had been the newly ennobled conservative Ove Høegh-Guldberg, but in April 1784 he was forced to resign after a coup d'état by the sixteen years old crown prince Frederick, who became prince-regent thereafter. Although 'the Crown' had to sign most decrees concerning Iceland, the actual decision making was left to lower administrative bodies, especially the Rent Chamber (Rentekammeret, the finance department), which issued orders to and received annual reports from the Icelandic officials.

There was no nobility in Iceland. The highest official on the island was the governor (stiftamtmaður); in 1783 the office was held by a benevolent, but elderly and sickly Norwegian named Lauritz Thodal. In north and east Iceland he was represented by the deputy governor Stefán Pórarinsson, an energetic young Icelander who had only been appointed to the post in summer 1783, replacing his uncle Ólafur Stephensen. Under them stood the roughly twenty district commissioners (sýslumenn). On an even more local scale, the communal overseers (hreppstjórar) organised local matters, especially poor relief. The clergy (2 bishops, deans, and parsons) also performed certain administrative tasks, such as keeping parish records and co-organising poor relief.

The Rent Chamber also gave orders to the director and local representatives of the trade company (see sect. 3.3), which organised all trade with Iceland and in fact all transport to and from the island. The chief executive, Carl Pontoppidan, was situated in Copenhagen, while the trade representatives stayed in Iceland. The latter were supposed to cooperate with the Icelandic officials.

The whole government system was rather top-down, authoritative and inflexible. However, as crossing the North Atlantic in the stormy season was considered infeasible, no communication was possible between Iceland and Copenhagen during the winter, making it impossible for Icelandic officials to consult their superiors in the capital.

\section{$3.2 \quad$ Farming and Fishing}

The Icelandic economy and trade have been studied extensively by [Gunnarsson, 1980, Gunnarsson, 1983]. In this and the following subsection a brief summary is given.

Iceland was mainly a subsidence farming society without urban centres (the largest settlement, Reykjavík, had about 200 inhabitants). Probably it was the poorest country of Europe. Farming was limited by the cool climate; grain would not grow, vegetable patches were scarce, and farmers mainly kept cows and sheep for food, clothes (wool) and light (tallow), and horses for transport; horse-drawn carts, roads, bridges or inland shipping hardly 
existed. Although most winters had mild intervals in which the animals could graze, the hey harvest was of utmost importance to keep the livestock alive. One icy winter or cool and wet summer often meant that some animals had to be slaughtered; two bad seasons in a row could easily bring famine, and thus, famines were common. Remarkably, large amounts of horse meat were wasted every year [Andrésson, 1984], due to religious traditions going back to a papal decree of 732AD which condemned the consumption of horse meat. Neither the reformation around 1550 nor the lifting of the legal ban on horse meat in 1757 put an end to this tradition. Even during the Haze Hardships, many people 'would rather die than eat it [i.e. horse meat]' [Steingrímsson, 1788, p. 82].

Iceland's poverty was not simply determined by its harsh climate, as the surrounding sea was rich in fish. Dutch and French fishermen frequently fished in Icelandic waters, and several contemporary scholars wrote that enhancing the fisheries was the only way to develop the Icelandic economy. Yet in the Icelandic farming society, fishing remained a sideline. In winter, when little farming work was possible, farmers or their workers travelled to the fishing camps in the southwest and west of the island, where fish was abundant in winter and spring and the conditions were favourable for wind-drying it. In northern and eastern Iceland, fish migration patterns and sea ice restricted fishing to the summer, but summer was hay harvest time, so people from these regions had to travel to the southwest to either participate in the winter fisheries or barter fish for farming products. The formation of fishing villages was prevented by a law prescribing that everybody had to be registered at a farm - either as farmer (owner or tenant) or as farmhand. Until 1783, it was possible for relatively well-off persons to obtain permission to be 'free labourers' (lausamenn), i.e. not registered at a farm; most free labourers lived in the fishing districts. In 1783, the landowning elite, always afraid to loose cheap labour for their farms, persuaded the Danes to ban free labourers - possibly to counter Danish attempts to incentivise fishing (see sect. 3.3.1). Fishing was also very hard and dangerous work, because it was performed at a low technological level, in open rowing boats; the vast majority of Icelanders lacked the means to invest in seaworthy decked vessels. In addition, the fish price had been kept artificially low by the Danish authorities for decades, making fishing even less attractive.

A good fishing season could compensate for a bad farming year and vice versa, but only to some extent. In the winter 1783-84, the fishing season was not bad, but the farmers in the rural areas, especially northern Iceland, could not benefit from it, as they were either too poor, too weakened or had too few horses left to make the exhausting journey to the southwest to purchase fish or work on a boat. The district commissioner of Snæfellsnessýsla, a main fishing district, complained that several boats in his district could not venture out for lack of healthy men from the north [Arnórsson, 1784].

\subsection{Monopoly Trade}

\subsubsection{The trade}

Iceland was not a self-sufficient economy: It depended on the import of building wood (for houses and boats), iron (tools) and hemp (fishing lines). Grain was also imported, but in normal years it was a luxury good rather than a necessity. As export goods, Iceland mainly offered wool products, sheep meat and hides, and dried fish. The trade was carried out by merchants or trade companies from Copenhagen who rented the Icelandic harbours from the Crown and had a trade monopoly. From 1774, the trade was carried out by a company run by the Crown, although part of the capital came from private shareholders. Iceland had around 25 trade harbours, which were mostly visited by one ship per harbour and per year, ships arriving in late spring and leaving in early autumn. In northern Iceland, sea ice occasionally prevented the ships from landing. In 1785, blocking of two harbours likely contributed to the high number of deaths in Húnavatnssýsla that year (see fig. 3).

Trade was mostly carried out as barter trade, partly because the merchants refused to pay in money, hoping that this would stimulate their customers to also buy luxury goods (brandy and tobacco), which were profitable to the merchants. However, the barter trade made it difficult for the farmers to save money for bad years or even for investing in better fishing boats. All prices were fixed by the Crown, mostly based on medieval Icelandic trading regulations called búalög. For many decades, fish prices in Iceland were very low compared to prices abroad, making dried fish a very lucrative export good for the merchants. Sheep meat was also profitable, while exchanging wool products for grain was not. This, together with the bartering, meant that in bad years, when the Icelanders had little fish or meat to offer, the trade often did little to alleviate the hardships, as the traders sometimes refused to hand out grain for woollen goods.

Nearly all work associated with trade - including manning the ships - was done by Danes; the traders were not allowed to employ Icelanders. While this law served the landowners to keep their cheap labour supply, it prevented the trade companies to re-invest any of their earnings into Iceland, thus impeding economic development.

Yet, when a commission ('the earlier land commission', landsnefndin fyrri) visited Iceland in 1770 to investigate how to develop its economy, they found that the monopoly trade was not unpopular with most conservative officials 
in Iceland (with the notable exception of the modern-minded treasurer Skúli Magnússon). The monopoly trade surely served to protect Iceland from price fluctuations abroad and its regulations ensured that also "meat harbours" (outside the fishing regions) in north and east Iceland were visited, thereby strengthening the farming sector - as did the relatively high prices for farming products. In the long run, however, the monopoly trade prevented economic development, mainly because the low fish prices made fishing unattractive for the Icelanders. In 1776, a new price list was introduced which increased the fish price, and even premiums were given to successful fishermen as additional incentive, but at least initially this measure did not entice the Icelanders to do more fishing. Other modernisation attempts initiated by the Danish government, such as bringing craftsmen to Iceland to instruct the local population [Oslund, 2011, p70], importing reindeer as alternatives to sheep [Oslund, 2011, p71 ff], or ordering farmers to level their ground and build fences [Lovsamling, vol.4, p.42-43], were likewise mostly unsuccessful. Whether these measures would have stimulated the economy in the longer run if the devastating Lakagígar eruption had not occurred, we cannot tell.

\subsubsection{Emergency arrangements to prevent famine}

The commission of 1770 also suggested to build emergency stores at all trading centres to prevent famine, e.g when a ship could not reach the trading harbour. This suggestion was not carried out. Instead, the trade regulations from 1776 stipulated that if widespread hunger threatened, the governor, deputy governor and district commissioners could ban the export of Icelandic foodstuff [Andrésson, 1984]. In addition, the merchants were obliged, in cooperation with the district commissioners and communal overseers, to give farmers in distress an emergency loan of foodstuff and tools, typically for one year. This rule was clearly meant as a temporary relief measure and did apply neither to officials, who were considered wealthy enough to not need emergency loans, nor to persons considered unlikely to be able to pay back the loan. However, it is doubtful whether this law could have prevented a nationwide famine, because the trade company did not have significant emergency stores of food in Iceland, particularly in winter. To make things worse, in early 1783, the authorities in Copenhagen felt that the emergency loans had been abused by persons not deserving them, including officials, and sent stern orders both to the merchants, who should collect outstanding debts and give fewer credits, and to the Icelandic officials to pay their debts and be less generous in suggesting ordinary farmers for loans [Andrésson, 1984].

\section{Capability: Disaster (mis)management}

Iceland clearly had insufficient resources to cope with a loss of about half of its cows and $3 / 4$ of its sheep, and the modest means at hand were ill used (see below). Therefore help would have to come from outside - from Denmark. Yet communication between the two countries was difficult, and the Danish authorities, although in principle willing to help, were slow to react.

\subsection{Troubled communication}

\subsubsection{Reports to Copenhagen in $\mathbf{1 7 8 3}$}

In the vicinity of the Lakagígar, sheep and cows died massively within weeks and thus the threat of a (local) famine quickly became imminent. Reverend Jón Steingrímsson of Kirkjubæjarklaustur, as the dean of Vestur- and AusturSkaftafellssýsla (see map in fig. 2), wrote several reports to the bishop in Skálholt, asking for financial aid for himself and other local parsons [Rafnsson, 1984b]. On July 4th, he also sent a letter to deputy governor Ólafur Stephensen (who was replaced in mid-July 1783 by Stefán Pórarinsson), which ends with a cautiously worded plea for government help: "May God have mercy upon us [...] and awaken the hearts of the officials so that they report the misery which befell this district to His Royal Majesty, who in His mercy will not let us die from hunger and wretchedness" [Steingrímsson, 1783]. Several weeks later, Ólafur Stephenson passed this letter on to Copenhagen along with his own report dated August 15th [Stephensen, 1783]. The governor, Lauritz Thodal, was even slower to inform the government about the eruption: His first report is dated September 16th [Gunnlaugsson and Rafnsson, 1984]. This was partly because he found it troublesome to extract reliable information from the district commissioner Lýdur Guðmundsson of Vestur-Skaftafellssýsla, who did not dare to visit the affected area because he feared that fiery cracks might open in the ground and swallow him. Apparently Thodal was unwilling to send a preliminary report for fear of being imprecise - a serious omission seeing that autumn was approaching and thus the time window for shipping over the North Atlantic was closing. The first news of the eruption received in Copenhagen were not an official report but a few, rather inaccurate remarks in a letter by merchant Peder Sünckenberg of Reykjavík to the directors of the trade company. His letter, dated July 24th, reached the capital at the end of August. 


\begin{tabular}{|c|c|}
\hline time & event \\
\hline \hline 1783, June 8 th & Onset eruption \\
\hline 1873, July & Letters of rev. Jón Steingrímsson to bishop \& deputy governor \\
\hline 1783, end of August & News of eruption reaches Copenhagen (letter from merchant) \\
\hline 1783, Oct. 11th & Investigation ship departs towards Iceland (but hibernates in Norway) \\
\hline 1784, winter-spring & Severe famine in Iceland, worst in the north \\
\hline 1784, January & Money collection in Copenhagen to aid Iceland \\
\hline 1784, February & Eruption ends \\
\hline 1784, April 14th & De-facto regent Guldberg disposed by crown prince Frederick \\
\hline 1784, April 16th & Investigation ship arrives in Iceland \\
\hline 1784, May 14th & Deputy governor asks Danes for fish transport to north \& econ. support \\
\hline 1784, July & Emissaries investigate Vestur-Skaftafellssýsla \\
\hline 1784, mid July & Full news of famine reaches Denmark; ca 440,000kg grain sent to Iceland \\
\hline 1784, Aug. 14th & Devastating earthquake in SW Iceland, destroying 400 farm houses \\
\hline 1784, Aug. 26th & Danish ship with orders concerning fish aid sinks off South-Iceland \\
\hline 1784, late summer & 1.2 million kg dried fish ( $\approx$ usual amount) exported from Iceland \\
\hline 1784, autumn onward & infectious disease ('landfarsótt') especially in western Iceland \\
\hline 1785, winter-spring & second hunger winter in Iceland \\
\hline 1785, February & Copenhagen: Commission founded; second money collection decided \\
\hline 1785, June 22 & several aid measures decided upon (though with limited success) \\
\hline 1785, summer & improving weather; famine ends \\
\hline 1785, Nov. - 1787, Mar. & small pox epidemic (unrelated to eruption?) \\
\hline
\end{tabular}

Table 2: Timeline of the eruption and measures taken.

In the regions further away from the eruption, although the eruption made itself felt with fine ash fall and sulphureous fog which inhibited fishing and spoilt the grass, massive decimation of livestock only manifested itself after several months, i.e. after the merchant ships had left the country.

\subsubsection{The investigation ship and Danish hibernation}

As mentioned, the first news of the eruption reached Copenhagen at the end of August 1783. It mentioned the destruction of two churches and eight farms by lava, thick sulphuric haze, bad grass growth and illnesses in grazing animals. About three weeks later, on September 17th, the Rent Chamber decided to send a ship to Iceland to investigate the situation [Gunnlaugsson, 1984b]. The ship was loaded with some grain, and aboard were two emissaries, the young lord-in-waiting and Rent Chamber member Hans C.D.V. von Levetzow "who likely desired soon to take the place of the current governor of Iceland" [Stephensen, 1888, p.229] and the student of law and natural science Magnús Stephensen, a son of the former deputy governor Ólafur Stephensen. They were ordered to investigate how best to help the victims, including fugitives, and which of the damaged farms could be made inhabitable again. In addition, Magnús Stephensen was told to investigate the eruption scientifically, including taking samples with an earth drill [Stephensen, 1785, p.XIV] to search for traces of lignite (at that time, one theory explained volcanic eruptions by subterranean coal fires, so this was cutting-edge science). They were also ordered to search and investigate a new island which had formed in spring 1783 off Reykjanes during a submarine eruption. The Danish authorities were anxious to take formal possession of this island to forestall other nations to use it as a base for fishing in Icelandic waters or even break the trade monopoly [Lovsamling, vol. 4, p.744ff]. They needn't have worried: The island was eroded before anyone found it again [Stephensen, 1888, p.252].

The ship departed another three and a half weeks after the Rent Chamber session, on October 11th. Around that time, further worrying news arrived from Iceland, including Thodal's report and Jón Steingrímsson's letter. The Danish authorities were now convinced that something serious was happening in southern Iceland (but had no idea that the north might also be affected). On October 23rd, the Crown issued an order [Lovsamling, vol. 4, p. 763-764] that needy persons in southern Iceland should obtain food from the trading posts without payment, under supervision of governor Thodal. This very appropriate order failed to have any effect, since no effort was made to carry it to Iceland before winter - the investigation ship had already left. The decree of October 23rd also approved a suggestion by Carl Pontoppidan, the executive of the royal Iceland trade, to collect money in Copenhagen to support the Icelanders. The collection was eventually held in January 1784 and yielded almost 10000 ríkisdalir (in Iceland, one ewe with lamb was worth 1 ríkisdalur) [Gunnlaugsson, 1984b]. 
Meanwhile, the investigation ship had run into several Atlantic autumn storms. After three attempts to reach Iceland, it took winter shelter near Kristianssand in southern Norway, and Levetzow returned to Copenhagen for the winter [Stephensen, 1888, , p.236-237]. Even though the Danish authorities were thus aware that the investigation ship had not reached its goal, no further attempts were made to reach Iceland. When Levetzow returned to Kristianssand to rejoin his ship end of February, he brought with him part of the collected money (1700 ríkisdalir), which was to be handed out to the farmers from the devastated area. The investigation ship departed again for Iceland in early March, but due to further inclement weather it only arrived there on April 16th 1784.

\subsection{Food aid and food trade}

\subsubsection{Loans and export bans (1783)}

Already in his letters to Thodal (July 26th 1783 [Guðmundsson, 1783a]) and the Rent Chamber in Copenhagen (August 2nd, 1783 [Guðmundsson, 1783b]), district commissioner Lýður Guðmundsson complained that the stricken inhabitants of his district were denied the customary emergency loans at the trade post and asked his superiors to persuade the merchant to hand out foodstuff for the needy. He did not mention any intention to try persuading the merchant by himself, even though district commissioners were co-responsible for overseeing the trade. It might have played a role in Lýður Guðmundsson's case that the nearest trading post, Eyrarbakki, was outside his district, but also many other district commissioners did often not succeed in forcing the merchants to give emergency loans. This was probably partly due to the recent orders regarding outstanding Icelandic debts (see section 3.3.2). Many Icelandic officials, trying to argue that these orders did not apply in case of actual famine, had a weak position because they themselves were indebted to the trade company and thus at the merchants' mercy, and the merchants were reluctant to disregard the recent letters without consent from Copenhagen [Pórarinsson, 1784, Andrésson, 1984]. This consent, of course, could not be obtained with winter approaching.

Similar difficulties arose concerning the ban of exporting Icelandic foodstuff [Andrésson, 1984]. The merchants had direct financial interests to export as much as possible from Iceland, because merchants received $1.5 \%$ of the value of their exports as top-up on wages and merchants' assistants $0.5 \%$. In late summer 1783 , the Icelandic officials did not enforce an export ban. Again, it was impossible to ask the opinion of the Danish authorities before the merchant ships left. Even though governor Thodal was entitled to decree an export ban on his own, he did not use his right. The same holds for the newly appointed deputy governor Stefán Pórarinsson, though in his part of Iceland, the threatening famine may not yet have been so obvious in summer 1783. As a result, no significant emergency stores were at hand in Iceland in autumn 1783.

In the course of the winter and spring 1784, the fishing season in southwestern and west Iceland was not bad, and the merchants succeeded in acquiring the usual amount of fish from Icelandic fishing boats: around 1.5 million $\mathrm{kg}$. In addition, the trade company caught fish with its own vessels. In spring 1784, Thodal banned the export of butter and tallow, but not fish (probably the most desired export good). Stefán Pórarinsson banned the export of all Icelandic foodstuff from his harbours until further notice; the merchants were obliged to sell such goods back to the population for the purchase price. But northern and eastern Iceland had only very limited fishing and, due to the livestock decimation, also very limited meat products, hence this export ban was little effective. Interestingly, in summer 1784 about 4400kg of dried fish were exported from Akureyri despite the ban [Andrésson, 1984].

\subsubsection{Further communication delays (spring 1784)}

As mentioned, the investigation ship (see sect. 4.1.2) arrived in Reykjavík on April 16th. By this time, governor Thodal was aware that the situation was grave in most of Iceland, i.e. over a much larger area than anticipated last autumn. On April 28th, he wrote: "The state in which Iceland now is, is without doubt [...] the worst that occurred since my arrival [in 1770]" [Thodal, 1784a] due to severe hay harvest failure, harsh winter weather and hence loss of sheep, horses and cows. Nonetheless, Thodal hesitated for about two months to send the investigation ship - or some incoming trading ship or the seaworthy vessels which the trade company employed for fishing - straight back to Copenhagen with the bad news.

The two emissaries, Levetzow and Magnús Stephensen, set off for Vestur-Skaftafellssýsla as late as July 2nd, partly due to lack of healthy horses [Stephensen, 1888, p.250]. On July 16th and 17th, Magnús Stephensen travelled in the highlands to find the volcano [Stephensen, 1785, p. $37 \mathrm{ff}$ ]. Due to the still hot and steaming lava flows, it was impossible to reach the crater row, and he mistook the hillock Laki for the source of the eruption. After some more days of inspecting damaged farms, the emissaries returned to Reykjavík in early August. As their ship had by then been sent back to Copenhagen, they returned to Denmark on another ship carrying the yearly load of royal falcons and arrived in early autumn. 
In northern Iceland, the sea ice blocked the coast until the end of May [Guðjónsson, 2010], preventing all communication by sea. On May 14th, deputy governor Stefán Pórarinsson wrote a lengthy report [Pórarinsson, 1784] to the Rent Chamber and sent it over land to Reykjavík, hoping that shipping would be possible from there. In his report, he submitted numerous suggestions on how to aid the impoverished and starving population. The most notable short-term measures suggested consisted in sending 8000 Danish tons ${ }^{1}$ (ca 667,000kg) of grain to North Iceland, and also a shipload of (low-quality) dried fish from the Icelandic fishing regions to the north. Part of the aid measures might be financed by a special tax on luxury goods such as brandy, tobacco, and coffee. In the longer run, the deputy governor suggested the donation of whaling ships, and stimulating employment for those who normally processed wool (which was now impossible due to the loss of sheep), e.g. by regulations against exporting unprocessed eiderdown, which should be processed within the country.

Stefán Pórarinsson's letter reached Copenhagen with the returning investigation ship in July 1784. Thodal's reports [Thodal, 1784b, Thodal, 1784c] do not indicate that he was familiar with the content. Either Stefán Pórarinsson did not inform Thodal or Thodal ignored his letter; but certainly Thodal did neither send Icelandic fish to the northern harbours nor decree a full ban on exporting Icelandic foodstuff [Andrésson, 1984].

\subsubsection{Flour and fish (summer 1784)}

In spring 1784 , the ordinary trading ships were sent to Iceland earlier than usual and given strict orders to do everything possible to reach their destination [Andrésson, 1984]. Should a harbour be blocked by sea ice, the ship should not return to Denmark but wait in the vicinity for the ice to break. However, no significant additional amount of foodstuff was shipped to Iceland this spring. (Compared to the 1764-1784 mean of 16950 tons, 24203 tons of grain were imported in 1784, i.e. 7073 tons above average; but of these, 5300 tons were only shipped after mid-July.)

On April 19th, the Crown issued a decree [Lovsamling, vol. 5, p. 45-46] that Thodal and Levetzow, together with the local administrators (district commissioners, deans and parsons), should collect information about which inhabitants were in need of food aid, and how help could be administered. It was decreed that no food aid was to be handed out unless under the supervision of Thodal or Levetzow. Local administrators were ordered to help with collecting information concerning the needs of the victims of the eruptions for aid (building material, animals, food) and the possibilities to relocate fugitives. The Danish authorities clearly still believed that the catastrophe was only regional, in particular, it did not occur to them that northern Iceland (the region hardest hit by the famine) might be affected at all [Gunnlaugsson, 1984b]. Also, the Danish officials apparently considered it essential to collect all possible data on the calamity prior to spending money on aid.

The only aid given in spring 1784 was a financial support for the farmers of Vestur-Skaftafellssýsla. When Reverend Jón Steingrímsson, the dean of the Skaftafell districts, arrived in Reykjavík in May (on foot, for lack of horses), Thodal handed him 600 ríkisdalir out of the collection money brought by Levetzow, and ordered him to bring this money to the local district commissioner Lýður Guðmundsson, who would distribute it among the needy farmers. However, on his way back, Jón Steingrímsson met several of his parishioners who were walking west in the hope to acquire livestock or means of subsistence, and handed out about 240 ríkisdalir on his own account. This act of disobedience brought about a lawsuit against the dean, but thanks to the intercession of his bishops, he was condemned only to a minor fine of five ríkisdalir and a public apology [Steingrímsson, 1791, Chapter 42-43].

As mentioned, the news of the devastating famine reached Copenhagen in July 1784. Now, quick decisions were finally made. On July 21st, it was decided to send 3000-4000 Danish tons of flour to Iceland [Lovsamling, vol. 5, p.99-100]; by autumn, 5300 tons had been sent [Lovsamling, vol. 5, p.106-107], of which 2800 tons (about 1/3 of the amount requested by the deputy governor) to the north. In addition, a letter dated July 17th was sent to Eyrarbakki, decreeing that part of the fish catch from West Iceland (which was of lower quality than the fish of Southwest Iceland) should be transported by the vessels of the trade company to the harbours where the need for food was greatest, i.e. northern and eastern Iceland. Although several ships with grain sailed to Iceland, only one set of letters concerning the fish was sent. Unfortunately, the ship carrying them was shipwrecked off the coast of Vestur-Skaftafellssýsla, and the letters got lost [Andrésson, 1984]. Governor Thodal and the district commissioners in the fishing regions still did not dare to declare a ban on exporting foodstuff without explicit orders from Denmark. Thus in late summer of 1784, the merchants exported nearly all fish they had acquired during the last spring, namely 7558 skippund $(=1,200,000 \mathrm{~kg})$ bought from Icelanders plus their own catches. No fish transports took place towards the north and east [Andrésson, 1984]. In the following winter, another several thousand Icelanders died, for a large part of starvation (or landfarsótt). $1,200,000 \mathrm{~kg}$ of fish could have provided $2000 \mathrm{kcal} /$ day to the 5649 persons who died in 1785 for roughly 10 months. Meanwhile, the Danish merchants profited considerably less from the fish than

\footnotetext{
${ }^{1}$ a grain ton was a volumetric measure, equal to 139 litres. It was specified that 1 ton of grain should weigh at least $83.4 \mathrm{~kg}$ [Gunnarsson, 1983, p. 41].
} 
expected: Fish prices, which had been unusually high during the American war of Independence, had dropped dramatically after the Treaty of Paris in summer 1783, from 0.17 ríkisdalir/kg (averaged over 1780-82) to 0.12 ríkisdalir/kg (1783-87) [Gunnarsson, 1983, p. 151].

Even the food aid which did reach Iceland was not necessarily effective, especially in the remote areas, due to the lack of horses required to transport food from the harbours overland. An attempt to ship some grain from the Vestmannaeyjar trading post to Dyrhólaey (see fig. 2) in the particularly remote Vestur-Skaftafellssýsla district was given up due to bad weather. Reverend Jón Steingrímsson complained that it would have been more effective to provide his parishioners with fishing and sealing gear, which would have allowed them to feed themselves to some extent [Steingrímsson, 1791, p. 84-85].

\subsection{The second year: Good intentions with meagre results}

\subsubsection{Total evacuation? (Autumn 1784)}

After the bad news of the famine in winter 1783/84, further bad tidings reached the Danish authorities in the course of the autumn: On August 14th, 1784, a severe earthquake had hit the southwest of the island, especially Rangárvallasýsla and Árnessýsla. Although the loss of life had been limited, several hundred farms and about 10 churches had been severely damaged or even completely collapsed [Guðjónsson, 2010].

It has long been claimed in Icelandic history books that the Danish authorities now considered Iceland uninhabitable and contemplated a complete evacuation by relocating the remaining Icelandic population to Jutland in Denmark. However, written protocols do not support this hypothesis, although it remains possible that a complete or at least large relocation has been considered orally and informally [Gunnlaugsson, 1984b]. What has been considered officially is moving 500-800 unproductive persons (the elderly and infirm, beggars and orphans) to Denmark. Apparently, this proposal lead to heated discussions in the Rent Chamber in early 1785. Levetzow suggested using the military in case the evacuees proved unwilling, while the high Rent Chamber official Jón Eiríkson (a native Icelander) considered the use of military forces against a peaceful population as a breech of law and pointed out that Iceland had no resources to feed hungry soldiers [Eiríksson, 1785]. The whole plan was given up shortly afterwards.

\subsubsection{Donations and Debts (1785 and beyond)}

In February 1785, a special commission (named 'the later land commission', landsnefndin síðari) was set up to investigate how to restore the Icelandic economy [Gunnlaugsson, 1984b, Lovsamling, vol. 5, p. 118-120; 124-127]. Among its members were Jón Eiríksson of the Rent Chamber, the executive board or the trade company, and Levetzow, who by then was appointed to replace the retiring Thodal as governor in April.

The commission decided to put an end to the aforementioned evacuation plans [Lovsamling, vol. 5, p. 216 ff], and to hold a second collection of money, this time in all market towns of Denmark-Norway [Lovsamling, vol. 5, p.123-124]. This took several months to organise, but eventually, about 36000 ríkisdalir were collected in 1785 [Gunnarsson, 1983, p.145]. Some further aid measures were decided upon [Gunnlaugsson, 1984b], and confirmed by royal decree on June 22nd, 1785 [Lovsamling, vol. 5, p. $216 \mathrm{ff}$ ]: Iceland was to be provided with food stores for the winter, and 4 shiploads of fish were to be sent to northern and eastern Iceland and sold to the local population for the purchase price (i.e. without charging freight costs). Farmers in need were to be provided with emergency loans from the trade, but only under careful supervision by the district commissioners. In addition, the trade company should put two ships at the new governor's disposal in case it would prove necessary to ship further goods among Icelandic harbours. Norwegian timber was to be sent to the harbour of Eyrarbakki and handed out to the victims of the earthquake who needed to rebuilt their homes [Lovsamling, vol. 5, p. 121-123 ff]. Timber and further material for building boats were also to be sent to the fishing districts of Gullbringusýsla and Snæfellssýsla, such that the fugitives from the North and Southeast could settle down as fishermen. Gouvernor Levetzow had to supervise the handing out of the timber. Finally, the Rent Chamber sent orders that spring to the district commissioners to count the population and the remaining livestock. In particular, it should be investigated which farms were in urgent need of additional livestock to remain inhabitable; it was planned to provide these farms with money (from the collection funds) to acquire animals.

Not all of these measured proved as effective as was hoped. The Danes sent almost twice as much grain as usual (32200 rather than 16950 Danish tons), and three (not four) shiploads of fish were sent to the northern and eastern harbours, but no other shipments in between harbours were made [Andrésson, 1984], and there were repeated complaints by the Icelanders that it was difficult to obtain goods at the trade posts, partly because they were badly stocked [Gunnlaugsson, 1984b]. Note also that the food aid was not a gift; it was sold (albeit without 
profit) or handed out as emergency loan to eligible people, i.e. farmers in acute distress who were however expected to pay their debts.

Concerning the timber, it appears that Levetzow was very hesitant to hand it out (even though it was already paid for by the collection money), setting up a complicated bureaucracy for the applicants to prove their need [Andrésson, 1984]. At the end, a good part of the timber, both in Eyrarbakki and the fishing districts, was never handed out but remained in the merchants' store and was sold in the course of time as ordinary merchandise. About the boat timber, Levetzow claimed that no new boats were needed because enough people had died the last two years to free up boat places for the fugitives, though it may be that he acted to please incumbent boat owners, who feared that new boats would make it more difficult for them to find labourers for their own vessels [Andrésson, 1984].

In some cases, fugitives were also sent back. For example, 40 paupers who had fled westward from eastern Vestur-Skaftafellssýla, were forced by Levetzow to return to their homes in early autumn 1785 . By law, paupers were entitled to poor relief in their home commune. However, the 90 remaining, impoverished inhabitants had no means to provide for the 40 returning fugitives, and even the charitable parson Jón Steingrímsson wrote that nothing could be done but 'simply finding them a place to die' [Steingrímsson, 1788, p. 88]. At the end, the parish was saved by an exceptional catch of seals, but the episode clearly illustrates how rigidly authorities applied the law, and that aid was far from sufficient.

Nonetheless, the acute famine ended in summer 1785 [Hálfdanarson, 1894], probably because the weather and the hay harvest were very good that summer [Guðjónsson, 2010]. However, many farms still suffered severe difficulties due to lack of livestock [Steingrímsson, 1788, p.87]. Already in April 1786 the Crown - under the impression of the past favourable weather and recent losses in the monopoly trade, inflicted by the eruption as well as low fish prices and high grain prices - ordered that fewer credits should be given in Iceland and debts be reduced as soon as possible [Lovsamling, vol. 5, p. 253-255]. These orders were given despite the significant amount of money gathered in the collection in 1785. The collected money remained largely unused and was saved as the so-called 'collection funds' in case Iceland should ever be hit by hardships again. The funds depreciated due to inflation and was eventually used in the 1840ies to construct a high school building in Reykjavík [Gunnarsson, 1983, p.145-146].

The attempt to aid farmers in urgent need for animals to replenish their livestock was not very successful: Not only was gathering the information a slow process, but what was worse, animals were scarce in the whole country, and it was nearly impossible to buy them [Gunnlaugsson, 1984b]. A Danish request to England in February 1785 to export some English sheep to Iceland had been refused as the English were keen to protect their wool export [Agnarsdóttir, 1992], and the Danes did not pursue the matter [Lovsamling, vol. 5, p. $216 \mathrm{ff}$ ]. Still, some money (from the collection funds) was handed out to farmers in the following years and may have been of some help, although, as Jón Steingrímsson remarked, 'A great number of farmers and farms could have been restored more quickly if the money, which was given to them for the purchase of livestock, had not been taken back for the payment of rents and other debts' [Steingrímsson, 1788, p.89]. The considerable amount of unpaid Icelandic debts with the trade company 1783-88 may have been due not to leniency, but to the fact that many debtors had died of hunger [Gunnarsson, 1984].

\section{$5 \quad$ Long-term effects of the Haze Hardships}

Perhaps surprisingly, the long-term effects of the eruption were limited.

Livestock was nearly restored after 12 years (see table 1). The population began to increase again after the smallpox epidemic of 1785-87; more people were born than died each single year from 1787 to 1801 , and in the decade 1791-1801 the population increase was 1-2\% each year [Gunnarsson, 1983, fig. 2.1]. This rapid increase may have been helped by the fact that in 18th century Iceland, over $1 / 3$ of the Icelanders never married, because marriage required access to land either though ownership or tenure, and farms were limited [Gunnarsson, 1983, p.13 ff]. Hence there was a 'reserve' of unmarried labourers who could take over the deserted farms and found a family.

The events of 1783-85 made a small contribution towards urbanisation in Iceland: As the southern bishop's see in Skálholt had been largely destroyed by the earthquake of 1784, the later land commission decided to relocate it to Iceland's largest settlement, Reykjavík, then a village of about 200 people, which became the administrative centre of Iceland in the following years.

Although the old treasurer Skúli Magnússon remarked in 1784 that 'it looks as if nature is teaching the people to show in the future increased carefulness and to have better control over the economy' (cited in [Gunnarsson, 1980]), there was no 'building back better' of the economic system. The farming crisis could have lead to an abandonment of the most precarious farms and the establishment of fishing villages, maybe as a continuation of the (relatively ineffective) attempt in 1785 to provide fugitives the means to settle in southwest Iceland as fishermen (see sect. 
4.3.2). However, neither was the vicious circle between poverty and the lack of seaworthy boats broken, nor were the laws changed which forced each individual to be registered at a farm (and hence forbade the formation of permanent fishing villages). Thus, for the next decades, Iceland remained a poor subsidence farming community. The only significant step towards economic modernisation was the abolition of the monopoly trade in 1787/88 [Lovsamling, p. $416 \mathrm{ff}]$. This measure was taken not so much to improve the freedom of the Icelandic population, but rather served to save government money: The Haze Hardships and unfavourable price changes abroad had rendered the previous trade company bankrupt [Gunnarsson, 1983, p.148-149]. After 1788, the Iceland trade was free for all subjects of the Danish Crown, including the Icelanders themselves, although direct trade between Iceland and foreigners remained forbidden, as the Danes feared that such trade would eventually result in the loss of their sovereignty over the island. On the one hand, this new trade regulation allowed Icelanders to become involved in the trade. On the other hand, during the French Revolutionary Wars, new difficulties arose: Now the merchants were no longer obliged to visit Iceland annually (as had been the case during the monopoly period), they found it more profitable to use their neutral status to trade between European belligerents, rather than undertake the perilous journey to the remote Iceland, so severe shortages loomed there. An Icelandic appeal in 1795 to the Danish authorities to open the Iceland trade to foreign nations was not granted [Agnarsdóttir, 2013, p.27].

The Danish request in 1785 to import English sheep to Iceland had a rather bizarre aftermath, namely repeated attempts by British individuals, most notably Sir Joseph Banks of the Royal Society, to bring about a British annexation of Iceland to free the island from the 'Egyptian bondage' of Danish rule [Agnarsdóttir, 1992]. These events culminated in the farcical 'Icelandic Revolution' of 1809, which did nothing to end Danish dominion, but helped to trigger the British government to magnanimously ensure the provision of Iceland with vital imports, as long as the sea blockade of the Napoleonic wars impeded the Danes from doing so.

In summary, although the Haze Hardships were perceived as a dramatic event and had inflicted much suffering in Iceland, they did not bring a turning point in history.

\section{Discussion: Was 'something rotten in the state of Denmark'?}

After the previous, mostly descriptive sections, one may discuss in which respects the reactions to the Lakagígar disaster were adequate, or not - and whether any lessons can be drawn from the events. This question will be treated first by briefly examine Danish pre-famine attempts to develop Icelandic economy, which determined the vulnerability to famine (sect. 6.1). Next, the magnitude of the disaster aid expenditure (sect. 6.2) will be discussed, and finally, the way in which these resources were put to use (sect. 6.3).

\subsection{Development aid without structural change}

Were the Danes to blame for Icelandic poverty and lack of resilience, as the 19th century nationalists claimed? Surely, Icelandic autonomy had declined in preceding centuries: With the reformation around 1550, the Catholic church had been abolished as authority on the island and much church land passed to the Crown; absolutism was introduced in 1662, and in 1602 the king established the monopoly trade [Gunnarsson, 1983, p. 53] to ensure that only his own subjects would enjoy the benefits of trade with Iceland. Iceland clearly was expected to yield revenue to the Crown. For example, in 1684 the king, short of money after a war with Sweden, thoughtlessly changed the trade price list to the disfavour of the Icelanders, such as to be able to extract higher harbour rents from the merchants; his successor had to revert the change in 1703 after several years of famine in Iceland [Gunnarsson, 1983, p. 55-56]. On the other hand, Iceland was maybe not treated worse than the Danish peasantry, let alone Danish colonies. As opposed to the Danish peasants, Icelanders did not live under serfdom (stavnsbåndet) and were not required to serve in the military.

With the age of Enlightenment, Danish treatment of Iceland changed. There were now active attempts to modernise the Icelandic economy. In the 1750ies, the treasurer Skúli Magnússon had persuaded the king to provide capital to develop manufactures in Reykjavík, mostly processing wool; the project failed due to, amongst other things, lack of inner-Icelandic markets for its products (farmers weaved their own cloth) and quarrels with the monopoly traders who refused to export the manufactured goods. In the following decades, the Danish government made some efforts promote development (see sect. 3.3.1), but these were mostly small-scale measures and had little effect. Attempts to stimulate fishing were almost bound to be unsuccessful due to the laws restricting free labour; inconsistently, these laws were sharpened rather than abolished in early 1783 under the pressure of the landowning elite. Maybe the optimistic officials in the Rent Chamber underestimated the conservatism of the landowners and the lack of entrepreneurship among common farmers who mostly were more occupied with surviving than with pursuing economic improvement [Gunnarsson, 1980]. The modern aim of (economic) 'progress' was only beginning to emerge 
in Europe [Ferguson, 2018, , chapter 2] and was slower still to penetrate Iceland's rural, pietist community. Danish policy since the reformation had contributed towards reducing Icelandic autonomy and sustaining the poverty trap of rural subsidence, and the benevolent, but half-hearted 'development aid' bestowed by optimistic enlightened rulers in the second half of the 18th century failed to bring about a structural change and improve prosperity and (hence) resilience to famine.

As a side remark, although colonialism, absolute monarchy and royal trade monopolies are clearly things of past times, the old Icelandic society exhibited, or even exaggerated, some features of many present-day developing countries. It was a subsistence agricultural economy which heavily depended on trade to obtain investment goods (tools, building material). This trade was in the hand of a multinational company which operated from, and hired staff in, a more developed country (Denmark), and sold high-quality 'cash crops' it procured (wind-dried fish) as a luxury good to the rich in foreign countries (the catholics in Southern Germany and the Mediterranean). Maybe 18th century Iceland provides an early illustration of the difficulties of 'developing' a backward economy from behind a clerk's desk, with insufficient understanding of the local conditions and societal fabric, especially while maintaining an initiative-stifling trade system.

\subsection{Greedy or generous? The magnitude of Danish aid}

Over the years 1783-87, the Danish Crown supported the trade company with 76209 ríkisdalir to finance emergency grain import to Iceland (and, to a much lesser extend, the Faroe Islands). In addition, the trade company incurred losses of about 460000 ríkisdalir with the Iceland trade in 1784-1788, which hit both the Crown (ca. 260000 ríkisdalir) and private shareholders [Gunnarsson, 1983, p.142,144]. It has been argued that these losses can partly be seen as indirect aid (e.g. unpaid Icelandic debts), while a substantial part of these losses was also caused by changing market prices outside Iceland and liquidation of the company 1787-88 [Gunnarsson, 1983, p.146 ff]. The money raised during the collections in 1784 and 1785 as about 46000 ríkisdalir in total, but much of it remained unspent.

To assess whether this amount was 'large' or 'small', consider a few comparisons. In the traditional Icelandic price system, one ewe with a lamb cost 1 ríkisdalur and one good milking cow 6-7 ríkisdalir. In summer 1784, ca. 31000 ríkisdalir were spent to purchase and transport to Iceland 5300 Danish tons of flour [Lovsamling, vol. 5, p. 215-216], enough to provide 40000 people with $2000 \mathrm{kcal} /$ day for ca. 20 days (assuming $83.4 \mathrm{~kg} / \mathrm{Danish}$ ton and $3460 \mathrm{kcal} / \mathrm{kg}$ flour). As this grain was not necessarily handed out for free in Iceland, the actual costs may have been lower than the initial costs of 31000 ríkisdalir. Note that 5300 tons for whole Iceland is much less than the amount requested by Deputy governor Stefán Pórarinsson, who asked for a shipment of 8000 tons to northern Iceland alone. The 1.2 million $\mathrm{kg}$ of fish which were exported in summer 1784 would have cost 54000 ríkisdalir in Iceland (abroad, prices were considerably higher). These comparisons show that the government expenditure after the Lakagígar eruption was a significant amount of money by Icelandic standards, but certainly not enough to completely mitigate food shortage during the 1.5 years of the Haze Hardships, let alone to compensate for the loss of livestock (see table 1) and damages to pastures and buildings brought about by the eruption and the subsequent earthquakes. Compared to other Crown expenditures, these relief costs are actually quite modest. For example, in the early 1780ies, the Crown had funded 3 new trade companies, partly with capital from private share holders. When these companies went more or less bankrupt after the end of the American war of Independence, the Crown decided to compensate the shareholders for their lost capital and non-forthcoming profits by paying them 7.8 million ríkisdalir over the next years, 100 times as much as the direct aid for Iceland [Gunnarsson, 1983, p.141]. Another, albeit trifling, expenditure may illustrate royal priorities. In normal years, the Crown would import 50 falcons from Iceland, but in early 1785 it was feared that no oxen could be purchased there to feed the falcons during the journey to Denmark. It was thus decided to limit the import to 30 falcons and send 20 living oxen to Iceland, to feed not the starving Icelanders but the royal falcons. The additional costs (including rebuilding the falcon ship to transport the oxen) were estimated to be 1896 ríkisdalir [Lovsamling, vol. 5, p. 128-129]. These two examples suggest that given the will, the Danish Crown could have afforded to spend more to save its Icelandic subjects from starvation.

The Danish reaction the Lakagígar eruption has been criticised both by contemporary and later authors, especially by 19th century Icelandic nationalists who considered it a prime example of harmful Danish influence on their island [Gunnarsson, 1984, Oslund, 2011, p. 45]. However, large-scale government relief was by no means the obvious reaction to famine in earlier centuries [Gunnarsson, 1980]; this not only holds before the Lakagígar eruption, but also 65 years later, e.g. during the Irish potato famine 1845-49. During that episode, initial relief schemes were gradually abandoned and the large food exports from Iceland were not banned for fear of disturbing the market. Unlike in Iceland 1783-84, this cannot be explained by unreliable transport and troubled communication over a stormy North Atlantic, but rather by a lack of political will: In the 1840ies the 'Laissez-faire' ideology had much influence on policy and government interference was considered harmful since 'if left to the natural law of distribu- 
tion, those who deserve more would obtain it' [Ó'Gráda, 2000, p.6-7]. The Lakagígar eruption, on the other hand, took place during a relatively enlightened period in which it was considered good governance to actively foster the economic activity of a country's subjects and to mitigate famine [Gunnarsson, 1984, Gunnarsson, 1980]. Thus, however insufficient, belated and clumsy the Danish aid may have been, one should acknowledge that they at least tried to help.

\subsection{A case study in disaster (mis)management?}

If the Danish officials were willing to help, why was their attempt not more successful?

The first step to take measures is to detect the threatening disaster and raise alarm. Local authorities in Iceland took a long time to realise that the Lakagígar eruption might have severe impacts beyond the area closest to the volcano. In particular governor Thodal lost crucial time trying to confirm information prior to writing to Copenhagen, for fear of risking a false alarm (see sect. 4.1.1). To be fair, eruptions with such widespread effects are not common in Iceland, but ash fall was detected throughout the country and the poisoning effect of volcanic ash was known [Pétursson et al., 1984]. Interpreting early warning signals of a famine is still a difficult issue [Hillier and Dempsey, 2012].

One important problem was undoubtedly communication troubles. When the full extent of the famine became obvious in the course of the winter, Iceland had no means to communicate with the outside world. Although sailing Icelandic waters in winter was considered impossible, a cautious government could have stationed a postal ship on the island each winter to be ready to sail in spring (this basic postal service was set up with a royal decree in 1787 [Lovsamling, vol. 5, p. 432]). This way, the news of the famine could have reached Copenhagen about 3 months earlier in 1784, thus significantly enhancing the time window for action before the next winter. Communication from Denmark to Iceland did not go smoothly, either, especially when the ship carrying orders concerning export bans got shipwrecked in August 1784. Of course, this was partly bad luck, but it was well known that the coast of Iceland was dangerous, so it would only have been prudent to send spare copies of the letters with each of the four ships sent to Iceland in late summer 1784. In other words, communication lines were not only long, but also lacked resilience, and the government did not take into account the possibility of accidents. Although of course communication speed has increased immensely since 1783, it should be noted that many disasters unfold over time scales of hours-days, rather than months, requiring much faster communication, and resilient communication lines remain vital [Keating et al., 2016].

Communication troubles can be mitigated by other measures. One approach could be to have competent local representatives and to give them discretion to implement measures on their own. However, the top-down administrative system of absolutist Denmark rather stifled initiative. Both local officials (governor, district commissioners) and trade representatives frequently delayed decisions waiting for detailed orders from Copenhagen. This attitude was likely stimulated by the central government. For example, the decree with which Stefán Pórarinsson was appointed deputy governor in 1783 [Lovsamling, vol. 4, p. $728 \mathrm{ff}$ ] repeats frequently that if certain circumstances should arise, he should seek advice from his superiors in the capital, mostly the Rent Chamber and the Chancellory. Another example is the lawsuit against Jón Steingrímsson (see sect. 4.2.3) who was sanctioned for showing too much initiative by disobeying not the spirit, but the letter of Thodal's orders.

Lacking both adequate communication and trust in local representatives, another measure could be to set up in advance well-designed emergency plans which the local authorities simply have to carry out. Obviously, this method requires a deep knowledge of the local situation by the central planners, as well as very clear instructions. The laws concerning possible export bans and loans for needy farmers can be seen as an attempt of an emergency plan (although it would have been more potent if backed up by significant emergency stores on the island). However, when famine loomed, there seems to have been confusion as to what was an 'emergency' and who was 'eligible' for a loan. The Danish government had further undermined its own emergency plan in early 1783 by sending letters concerning the need to reduce Icelandic debts, underestimating the tendency of Icelandic authorities and trade representatives to follow the most recent instructions rather than the overarching goal of preventing starvation. As described in sect. 6.2, the Danish government formulated in autumn 1783 a clarification that loans were still to be given in emergencies, but no effort was taken to send it to Iceland before spring 1784.

Another difficulty diminishing the efficiency of aid were conflicts of interests. The most striking one is the multitude of roles of the trade company. Being the only organisation providing transport to Iceland, and the only owner of significant food stores on the island (at least between the fishing season in spring and the departure of the trade ships in summer), it was the instrument through which the government could administer relief. At the same time, the trade company was a commercial enterprise, and both the shareholders (including the Crown) and the employees in Iceland expected to make profit from it. On the Copenhagen end, the Crown could, if it wished, override the shareholders' economic interests and decree that unprofitable rescue actions be carried out. However, 
the trade representatives in Iceland had a strong financial incentive to export as much from the island as they could, and thus to oppose any attempt by Icelandic officials to ban export. They also refused in some cases to put their large fishing vessels at the disposal of the governor for transporting foodstuff, possibly because they considered fishing more profitable. Maybe the central government did not foresee this problem; at least no reference regarding financial compensation is made in the order of July 21st, 1784, which stated that local tradesmen should 'provide their Hukkerter [fishing vessels] to transport fish and other foodstuff from one district to the other'.

Finally, the Danish government proved unwilling to take serious action in view of incomplete information. For example, given the disturbing, but unclear news that had reached Copenhagen by winter 1783/84, the government could have chosen for a 'least regret' option and send a substantial additional amount of grain to Iceland in early spring, even while not being sure whether it would be needed. Of course, this would have been costly in the short run, but if the situation had turned out less serious, the surplus grain could have been stored and less been sent in 1785. The extra cost of sending too much grain in the absence of famine should have appeared much less severe then the loss of human life brought about by not sending the grain in the presence of famine. But instead of acting decisively based on a plausible worst-case scenario, valuable months were spilled waiting for the return of the exploration ship and sending repeated requests to the Icelandic officials in the region nearby the Lakagígar for careful surveys of population, fugitives, livestock etc. In the words of Jón Steingrímsson, who as dean was co-responsible for gathering this information, 'These [census lists] could hardly be expected to make sense or to agree, as people were constantly moving back and forth and some dying' [Steingrímsson, 1788, p. 86]. In any way, collecting information in the large, thinly populated Iceland was a tedious business, and the data could be shipped to Copenhagen only with the ships departing in autumn, so that they would be acted upon only in the next year. In spring 1785, renewed requests for a careful survey of livestock and human population were sent to the whole of Iceland, partly to assess which farms were in need of assistance to buy livestock. From many districts, this information was delivered only in 1786. In short, it seems that the Danish government was so afraid to incur aid expenditures that might later prove unnecessary, that it preferred to delay action by a year or more and risk that the aid might come too late to do any good.

If one tries to find one single expression describing the Danish attitude, it is naive optimism. The Danish officials hoped that the effects of the eruption would not be too bad, trusted that information from and its own orders to Iceland would be transmitted smoothly, that all (sometimes unclear) orders would be carried out immediately and effectively, with officials and trade representatives functioning perfectly without frictions such as competing interests. Maybe a more efficient aid could have been accomplished if the officials had constantly asked themselves: How can this measure go wrong - and what can be done to mitigate potential failure? But this would have required foresight, imagination, and an intimate knowledge of the local geographical and societal situation - or, maybe, experience from the past.

\section{Funding:}

This research did not receive any specific grant from funding agencies in the public, commercial, or not-for-profit sectors.

\section{Acknowledgements:}

This article was inspired by a symposium held at the Centre for Complex Systems Studies at Utrecht University.

\section{References}

[Agnarsdóttir, 1992]

[Agnarsdóttir, 2013]

[Andrésson, 1984]
Agnarsdóttir, Anna, 'Scottish plans for the annexation of Iceland 1785-1813', Northern Studies 29: 83-91, 1992

Agnarsdóttir, Anna, 'Iceland in the Eighteenth Century: An Island Outpost of Europe?', Sjuttonhundratal. 10. 11. 10.7557/4.2619, 2013.

Andrésson, Sigfús H., 'Aðstoð einokunarverslunarinnar við Íslendinga í Móðuharðindum' (Support of the monopoly trade to the Icelanders during the Haze Hardships), in: 'Skaftáreldar 1783-84: ritgerðir og heimildir' (The Lakagígar eruption 1783-84: articles and sources), Mál og Menning, Reykjavík, 1984, p. 215-234. 
[Arnórsson, 1784]

[Bell and Davis, 2001]

[d'Arrigo et al., 2011]

[Eiríksson, 1785]

[Ferguson, 2018]

[Grattan et al., 2003]

[Guðjónsson, 2010]

[Guðmundsson, 1783a]

[Guðmundsson, 1783b]

[Gunnarsson, 1980]

[Gunnarsson, 1983]
Arnórsson, Jón, Report to the Danish authorities, Sept. 30th, 1784, printed in 'Skaftáreldar 1783-84: ritgerðir og heimildir' (The Lakagígar eruption 1783-84: articles and sources), Mál og Menning, Reykjavík, 1984, p. 303319.

Bell, Michelle L., and Devra L. Davis, 'Reassessment of the Lethal London Fog of 1952: Novel Indicators of Acute and Chronic Consequences of Acute Exposure to Air Pollution', Environmental Health Perspectives 109 Suppl 3(Suppl 3):389-94, 2001

D'Arrigo, Rosanne, Richard Seager, Jason E. Smerdon, Allegra N. LeGrande, and Edward R. Cook, 'The anomalous winter of 1783-1784: Was the Laki eruption or an analog of the 2009-2010 winter to blame?' , Geophys. Res. Lett., 38, L05706, 2011

Eiríksson, Jón, Notes for a Rent Chamber meeting on the Haze Hardships on January 14th, 1785, printed in: 'Skaftáreldar 1783-84: ritgerðir og heimildir' (The Lakagígar eruption 1783-84: articles and sources), Mál og Menning, Reykjavík, 1984, p. 423-435.

Ferguson, Peter, 'Post-growth Politics. A Critical Theoretical and Policy Framework for Decarbonisation', Springer Nature, 2018.

Grattan, J., M. Durand and S. Taylor, 'Illness and elevated human mortality in Europe coincident with the Laki Fissure eruption', In: Oppenheimer C, Pyle DM, Barclay J (eds), Volcanic Degassing. Geological Society Special Publications 213, London, pp 401-414, 2003

[Guðbergsson and Theodórsson, 1984] Guðbergsson, Gylfi M., and Theodór Theodórsson, 'Áhrif Skaftárelda á byggð og mannfjölda í Leiðvallahreppi og Kleifahreppi' (Consequences of the Lakagígar eruption on settlement and population numbers in Leiðvallahreppur and Kleifahreppur), in: 'Skaftáreldar 1783-84: ritgerðir og heimildir' (The Lakagígar eruption 1783-84: articles and sources), Mál og Menning, Reykjavík, 1984, p. 99-118.

Guðjónsson, Sigurður 'Íslenskir annálar og aðrar gamlar veðurheimildir' (Icelandic annals and other old weather sources), 2010. Accesed online in Augist 2019 at https://www.vedur.is/media/vedurstofan/utgafa/hlidarefni/annalar_sigth.pdf.

Guðmundsson, Lýður, Letter to governor Thodal, July 26th, 1783, printed in: 'Skaftáreldar 1783-84: ritgerðir og heimildir' (The Lakagígar eruption 1783-84: articles and sources), Mál og Menning, Reykjavík, 1984, p. 276278.

Guðmundsson, Lýður, Letter to the Rent Chamber, August 2nd, 1783, printed in: 'Skaftáreldar 1783-84: ritgerðir og heimildir' (The Lakagígar eruption 1783-84: articles and sources), Mál og Menning, Reykjavík, 1984, p. 283-286.

Gunnarsson, Gísli, 'A Study of Causal Relations in Climate and History: With an Emphasis on the Icelandic Experience', Lund 1980. Accessed online in August 2019 under https: $/ /$ books.google.it/books?id $=4 \mathrm{Rk} \_$AQAAMAAJ\&printsec $=$frontcover $\& \mathrm{hl}=\mathrm{nl} \# \mathrm{v}=\mathrm{on}$

Gunnarsson, Gísli, 'Monopoly Trade and Economic Stagnation. Studies in the Foreign Trade of Iceland, 1602-1787', PhD thesis at Lund University, 1983. Accessed online in August 2019 at https://babel.hathitrust.org/cgi/pt?id $=$ uc1.b3524053\&view $=1 \mathrm{up} \&$ seq $=6$. 
[Gunnarsson, 1984]

[Gunnlaugsson, 1984a]

[Gunnlaugsson, 1984b]

[Gunnlaugsson and Rafnsson, 1984]

[Gupta et al., 1996]

[Hálfdanarson, 1894]

[Halldórsson, 2013]

[Hillier and Dempsey, 2012]

[Keating et al., 2016]

[Lanciki et al., 2012]

[Magnússon, 2010]

[Ó'Gráda, 2000]

[Ó'Gráda, 2007]

[Oman et al., 2006]
Gunnarsson, Gísli, 'Voru Móðuharðindin af manna völdum?' (Were the Haze Hardships caused by men?), in: 'Skaftáreldar 1783-84: ritgerðir og heimildir' (The Lakagígar eruption 1783-84: articles and sources), Mál og Menning, Reykjavík, 1984, p. 235-242

Gunnlaugsson, Gísli Á., 'Fólksflótti úr Vestur-Skaftárfellssýslu í kjölfar Skaftárelda' (Emigration from Vestur-Skaftárfellssýsla following the Lakagígar eruption), in: 'Skaftáreldar 1783-84: ritgerðir og heimildir' (The Lakagígar eruption 1783-84: articles and sources), Mál og Menning, Reykjavík, 1984, p. 119-128.

Gunnlaugsson, Gísli Á., 'Viðbrögð stjórnvalda í Kaupmannahöfn við Skaftáreldum' (Reaction of the central government in Copenhagen during the Lakagígar eruption), in: 'Skaftáreldar 1783-84: ritgerðir og heimildir' (The Lakagígar eruption 1783-84: articles and sources), Mál og Menning, Reykjavík, 1984, p. 187-214.

Gunnlaugsson, Gísli A., and Sveinbjörn Rafnsson, Comments on the historical sources (group II) reproduced in 'Skaftáreldar 1783-84: ritgerðir og heimildir' (The Lakagígar eruption 1783-84: articles and sources), Mál og Menning, Reykjavík, 1984, p. 271-272.

Gupta, Sunil K., Ramesh C. Gupta, Ashoka K. Seth, Alka Gupta, 'Reversal of fluorosis in children', Pediatrics International, 38: 513-519, 1996. doi: https://doi.org/10.1111/j.1442-200X.1996.tb03536.x.

Hálfdanarson, Guðmundur, "Mannfall í Móðuharðindin" (Human mortality during the Haze Hardships), in: 'Skaftáreldar 1783-84: ritgerðir og heimildir' (The Lakagígar eruption 1783-84: articles and sources), Mál og Menning, Reykjavík, 1984, p. 139-162.

Halldórsson, Eypór, 'The Dry Fog of 1783: Environmental Impact and Human Reaction to the Lakagígar Eruption', MA thesis, Vienna, 2013. Accessed online in August 2019 at https://skemman.is/handle/1946/17205?locale $=$ en.

Hillier, Debbie, and Benedict Dempsey, 'A Dangerous Delay. The cost of late response to early warnings in the 2011 drought in the Horn of Africa', Oxfam Policy and Practice: Agriculture, 2012

Keating, Adriana, Kanmani Venkateswaran, Michael Szoenyi, Karen MacClune, and Reinhard Mechler, 'From event analysis to global lessons: disaster forensics for building resilience', Nat. Hazards Earth Syst. Sci., 16, 16031616,2016

Lanciki, Alyson, Jihong Cole-Dai, Mark H. Thiemens, Joël Savarino, 'Sulfur isotope evidence of little or no stratospheric impact by the 1783 Laki volcanic eruption'. Geophysical Research Letters, 39(1), 2012

Magnússon, Sigurður G., 'Wasteland with words', Reaktion Books, 2010.

Ó Gráda, Cormac, 'Black '47 and Beyond: The Great Irish Famine in History, Economy, and Memory', Princeton University Press, New Jersey, 2000

Ó Gráda, Cormac, 'Making famine history', Journal of Economic Literature, 45 (1): 5-38, 2007

Oman, Luke, Alan Robock, Georgiy L. Stenchikov, and Thorvaldur Thordarson, 'High-latitude eruptions cast shadow over the African monsoon and the flow of the Nile', Geophys. Res. Lett., 33, L18711, 2006 
[Oslund, 2011]

[Pétursson et al., 1984]

[Rafnsson, 1984a]

[Rafnsson, 1984b]

[Robock, 2000]

[Roholm, 1937]

[Schmidt et al., 2011]

[Schmidt et al., 2012]

[Sigurðsson and Bergsson, 1783]

[Steingrímsson, 1783]

[Steingrímsson, 1788]

[Steingrímsson, 1791]

[Stephensen, 1785]
Oslund, Karen, 'Iceland imagined. Nature, Culture and Story-Telling in the North Atlantic', Washington University Press, 2011.

Pétursson, Guðmundur, Páll A. Pálsson, and Guðmundur Georgsson: 'Um eituráhrif af völdum Skaftárelda' (on the poisoning effects of the Lakagígar eruption), in: 'Skaftáreldar 1783-84: ritgerðir og heimildir' (The Lakagígar eruption 1783-84: articles and sources), Mál og Menning, Reykjavík, 1984, p. $81-98$.

Rafnsson, Sveinbjörn: 'Búfé og byggð við lok Skaftárelda og Móðuharðinda' (Livestock and settlement at the end of the Lakagígar eruption and Haze Hardships), in: 'Skaftáreldar 1783-84: ritgerðir og heimildir' (The Lakagígar eruption 1783-84: articles and sources), Mál og Menning, Reykjavík, 1984, p. $163-178$.

Rafnsson, Sveinbjörn: 'Um eldritin 1783-1788' (On the descriptions of the eruption 1783-1788), in: 'Skaftáreldar 1783-84: ritgerðir og heimildir' (The Lakagígar eruption 1783-84: articles and sources), Mál og Menning, Reykjavík, 1984, p. 163-178.

Robock, Alan, 'Volcanic eruptions and climate', Rev. Geophys., 38, 191-219, 2000 .

Roholm, Kaj, 'Fluorine Intoxication, A Clinical-Hygienic Study with a review of the literature and some experimental investigations', Nyt Nordisk Forlag, Copenhagen, 1937.

Schmidt, Anja, Bart Ostro, Kenneth S. Carslaw, Marjorie Wilson, Thorvaldur Thordarson, Graham W. Mann, and Adrian J. Simmons, 'Excess mortality in Europe following a future Laki-style Icelandic eruption', PNAS 108 (38) 15710-15715, 2011

Schmidt, Anja, Thorvaldur Thordarson, Luke D. Oman, Alan Robock, and Stephen Self, 'Climatic impact of the long-lasting 1783 Laki eruption: Inapplicability of mass-independent sulfur isotopic composition measurements', Journal of Geophysical Research: Atmospheres, 117(D23), 2012

Sigurðsson, Jón, and Loftur Bergsson, Ping testimony from Svarfaðardalshreppur, December 4th, 1783, printed in 'Skaftáreldar 1783-84: ritgerðir og heimildir' (The Lakagígar eruption 1783-84: articles and sources), Mál og Menning, Reykjavík, 1984, p. 380-382.

Steingrímsson, Jón, 'Lítið ágrip um nýja eldsuppkomu í vestaraparta Skaftafellssýslu og bess verkarnir sem framkomnar eru' (A little summary on the new firy outburst in the western part of Skaftafellsýsla and the consequences thereof), letter to the deputy governor, July 4th, 1783, printed in 'Skaftáreldar 1783-84: ritgerðir og heimildir' (The Lakagígar eruption 1783-84: articles and sources), Mál og Menning, Reykjavík, 1984, p. 272-274.

Steingrímsson, Jón, "Fullkomið skrif um Síðueld" (Complete description of the Sída fires), 1788; transl. by Keneva Kunz as "Fires of the Earth. The Laki eruption 1783-84", University of Iceland Press, Reykjavík, 1998.

Steingrímsson, Jón, autobiography, 1791; transl. by Michael Fell as 'A very present help in trouble. The autobiography of the fire-priest', Peter Lang Publishing, Inc., New York, 2002

Stephensen, Magnús, 'Kort Beskrivelse over den nye Vulcans Ildsprudning i Vester - Skaptefields - Syssel paa Island i Aaret 1783' (Short description of the new volcanic eruption in Vestur-Skaftafellssýsla on Iceland in the year 1783), Copenhagen 1785. Accessed online in August 2019 at https://archive.org/details/KortBeskrivelseo000255771v0MagnReyk/page/n5. 
[Stephensen, 1888]

[Lovsamling]

[Stephensen, 1783]

[Thodal, 1784a]

[Thodal, 1784b]

[Thodal, 1784c]

[Thordarson et al., 2003]

[Thordarson and Self, 1993]

[Thordarson and Self, 2003]

[Thordarson and Höskuldsson, 2014]

[Whitham and Oppenheimer, 2004]

[Zambri et al., 2019a]
Stephensen, Magnús, Autobiography (incomplete), printed by Tímarit Hins íslenzka bókmentafélags, 1888. Accessed online in August 2019 at http://timarit.is/view_page_init.jsp?pageId=2317831.

Stephensen, Oddgeir, and Jón Sigurðsson (editors), 'Lovsamling for Island, indeholdende Udvalg af de vigtigste ældre og nyere Love og Anordninger, Resolutioner, Instructionere og Reglementer, Althingsdomme og Vedtægter, Collegial-Breve, Fundatser og Gavebreve, samt andre Aktestykker, til Oplysning um Islands Retsforhold og Administration i ældre of nyere Tider' (Law collection for Iceland, containing a selection of the most important elder and newer laws and orders, resolutions, instructions and regulations, Althing verdicts and by-laws, council letters, grants and endowment letters, as well as other documents, for information on Iceland's law system and administration in elder and newer times), Copenhagen 1854 (vol.4) and 1855 (vol.5), accessed online in August 2019 at https://baekur.is/bok/000195669/Lovsamling_for.

Stephensen, Ólafur, Extract from a letter to Jón Eiríksson of the Rent Chamber, August 16th, 1783, printed in 'Skaftáreldar 1783-84: ritgerðir og heimildir' (The Lakagígar eruption 1783-84: articles and sources), Mál og Menning, Reykjavík, 1984, p. 279.

Thodal, Lauritz A., Report to the Rent Chamber, April 28th, 1784, printed in 'Skaftáreldar 1783-84: ritgerðir og heimildir' (The Lakagígar eruption 1783-84: articles and sources), Mál og Menning, Reykjavík, 1984, p. 299301 .

Thodal, Lauritz A., Report to the Rent Chamber, June 17th, 1784, printed in 'Skaftáreldar 1783-84: ritgerðir og heimildir' (The Lakagígar eruption 1783-84: articles and sources), Mál og Menning, Reykjavík, 1984, p. 301302.

Thodal, Lauritz A., Report to the Rent Chamber, October 4th, 1784, printed in 'Skaftáreldar 1783-84: ritgerðir og heimildir' (The Lakagígar eruption 1783-84: articles and sources), Mál og Menning, Reykjavík, 1984, p. 302303 .

Thordarson, Thorvaldur, Guðrún Larsen, Sigurður Steinpórsson, and Stephen Self, 'The 1783-1785 A.D. Laki-Grímsvötn eruptions II: Appraisal based on contemporary accounts', JÖKULL No. 53, 11-48, 2003

Thordarson, Thorvaldur, and Stephen Self: The Laki (Skaftár Fires) and Grimsv6tn eruptions in 1783-1785, Bull Volcanol. 55:233-263, 1993

Thordarson, Thorvaldur, and Stephen Self: Atmospheric and environmental effects of the 1783-1784 Laki eruption: A review and reassessment, Journal of geopysical research, vol. 108, NO. D1, 4011, doi:10.1029/2001JD002042, 2003

Thordarson, Thor, and Ármann Höskuldsson, 'Iceland: Second Edition (Classic Geology in Europe)', Dunedin Academic Press, 2014

Witham, Claire, and Clive Oppenheimer, 'Mortality in England during the 1783-84 Laki Craters eruption', Bulletin of Volcanology. 67. 15-26, 2004

Zambri, Brian, Alan Robock, Michael J. Mills, and Anja Schmidt, 'Modeling the 1783-1784 Laki Eruption in Iceland: 1. Aerosol Evolution and Global Stratospheric Circulation Impacts', Journal of Geophysical Research: AtmospheresVolume 124, Issue 13, 2019 
[Zambri et al., 2019b]

[Pórarinsson, 1784]
Zambri, Brian, Alan Robock, Michael J. Mills, and Anja Schmidt, 'Modeling the 1783-1784 Laki Eruption in Iceland: 2. Climate Impacts', Journal of Geophysical Research: AtmospheresVolume 124, Issue 13, 2019

Pórarinsson, Stefán, Report to the Rent Chamber, May 14th 1784, printed in 'Skaftáreldar 1783-84: ritgerðir og heimildir' (The Lakagígar eruption 178384: articles and sources), Mál og Menning, Reykjavík, 1984, p. 303-319. 